\title{
ISTORIJA
}

\section{MYKOLO SLEŽEVIČIAUS POLITINÉ VEIKLA PIRMOJO PASAULINIO KARO METAIS}

Doc. DR. Mindaugas Tamošaitis

Vytauto Didžiojo universiteto Švietimo akademija Vytautas Magnus University Education Akademy T. Ševčenkos g. 31, LT-03111 Vilnius El.paštas mindaugas.tamosaitis@vdu.lt

\section{Santrauka}

Straipsnyje, remiantis gausiais šaltiniais, pagrindinis demesys skiriamas Mykolo Sleževičiaus politinei veiklai Pirmojo pasaulinio karo metais. Dèl neaiškių priežasčių istoriografijoje šio laikotarpio M. Sleževičiaus politinè veikla nebuvo tiriama. Tuo metu būsimo nepriklausomos Lietuvos ministro pirmininko veikla buvo aktyvi. Jam teko rūpintis nukentejusių nuo karo lietuvių pabègèlių šelpimu, išsakyti požiūrị dẻl Lietuvos ateities Rusijos lietuvių seime Petrograde, išreikšti poziciją kilus dideliems nesutarimams Lietuvos socialistų liaudininkų partijoje, vadovauti Vyriausiajai lietuvių tarybai Rusijoje, viešai išreikšti ideologines pažiūras ir ịžvalgas dèl Lietuvos nepriklausomybès perspektyvų 1918 m. pradžioje. Šiame straipsnyje analizuojama minèta M. Sleževičiaus veikla, o pabaigoje pateikiamos atlikto tyrimo išvados.

Reikšminiai žodžiai: Mykolas Sleževičius, Lietuvių draugija nukentèjusiems dèl karo šelpti (LDNKŠ), Rusijos lietuvių seimas Petrograde (RLSP), Lietuvos demokratų partija (LDP), Lietuvos socialistų liaudininkų partija (LSLP), Lietuvos socialistų liaudininkų 
demokratų partija (LSLDP), Lietuvos Taryba (LT), Lietuvos Valstybès Taryba (LVT), Lietuvių tautos taryba (LTT), Vyriausioji lietuvių taryba Rusijoje (VLTR).

\section{İvadas}

Mykolas Sleževičius - politikas, dalyvavęs kone visuose svarbiausiuose XX a. pirmosios pusés lietuvių politinio gyvenimo ịvykiuose. Iš pradžių jis aktyviai veikè Lietuvos demokratų partijoje (LDP), Pirmojo pasaulinio karo metais Rusijos lietuvių seime Petrograde (RLSP) vienas pirmųjų iškèlè Lietuvos nepriklausomybès idèją, vykstant lietuvių tautos kovoms dèl nepriklausomybès jis, kaip tuometis ministras pirmininkas, išleido garsųji atsišaukimą i Lietuvos savanorius, ragindamas juos stoti $\mathfrak{i}$ kariuomenę ir eiti ginti tèvynès. Net tris kartus ejo Vyriausybès vadovo pareigas, o po valstybès perversmo iki pat mirties (1939 m.) išliko autoritarinio valdymo kritiku. Be to, parlamentiniu laikotarpiu M. Sleževičius dirbo visuose demokratiškai išrinktuose Lietuvos parlamentuose, buvo ilgametis valstiečių liaudininkų partijos lyderis, apskritai, ypač parlamentiniu laikotarpiu, vienas įtakingiausių Lietuvos politikų ${ }^{1}$.

Istoriografija. Skirtingais laikotarpiais pasirodydavo darbų, kuriuose būdavo daugiau ar mažiau užsimenama ir apie M. Sleževičių politiką. Pirmiausia apie M. Sleževičių rašè jo bendražygiai ar artimos aplinkos asmenys. Dar paskutiniais nepriklausomos Lietuvos metais pasirodė M. Sleževičiaus idejjinio bendraminčio valstiečių liaudininkų lyderio Zigmo Toliušio nedidelès apimties brošiūra apie prieš metus mirusị M. Sleževičių. Kaip ir buvo galima numatyti, joje tik epizodiškai supažindinta su pagrindiniais aprašomo veikejo biografijos epizodais, tarp jų ir politine veikla Pirmojo pasaulinio karo metais ${ }^{2}$.

1 Römeris, M. Dienoraštis. 1921 m. lapkričio 8-oji-1922 m. birželio 15-oji. Vilnius, 2013, p. 34.

2 Toliušis, Z. Mykolas Sleževičius: biografijos bruožai. Kaunas, 1940. 
Mirus M. Sleževičiui, artimieji prikalbino Julių Būtėną parašyti apie ji monografiją. J. Būtènas, priklausydamas jauniesiems valstiečiams liaudininkams, artimai pažinojęs M. Sleževičių ir kitus jo artimos aplinkos politikus, èmési šio darbo. Ji pradejjo $1940 \mathrm{~m}$. pradžioje. Per trumpą laiką J. Būtėnui pavyko apklausti nemažai artimai M. Sleževičių pažinojusių asmenų. Apie tai būsimos monografijos autorius rašė dienoraštyje. Iš jo ịrašų paaiškèjo, jog J. Būtėnui per pusę metų (iki 1940 m. vasarą SSRS ịvykdytos Lietuvos okupacijos) pavyko parašyti nemažai knygos rankraščio teksto. Autorius, prieš pat Lietuvos okupaciją parašęs skyrių „IV ministerių kabineto pirmininkas“, ne kaip jautèsi: „Laužiau galvą, kaip toliau reikès rašyti: juk teisybės nepraleis cenzūra" (turètas omenyje tuometinis autoritarinis valdymas Lietuvoje - M. T.). O Lietuvą okupavus SSRS, J. Būtènas apsisprendẻ baigti knygos rašymą: „Kokia dabar galèjo būti prasmė toliau rašyti M. Sleževičiaus monografiją, kas ją leis, kam ji reikalinga? Juk netrukus svarbesnieji partijų veikejjai atsidurs už kalejjimo grotų. Prof. K. Sleževičius tada man sakè: „Laiku brolis pasimirè, o būtų dabar tąsomas“. Tuomet J. Būtẻnas nueję̨s pas M. Sleževičiaus žmoną Domą Sleževičienę jai atidavė du egzempliorius (originalą ir nuorašą). Ji apgailestavo, jog nebus toliau rašoma knyga $^{3}$. Tačiau po Antrojo pasaulinio karo atsidūrusi JAV D. Sleževičienè išsaugojo rankraštị, ir jis buvo panaudotas po 14 metų išeivijoje net 11 autorių kolektyvo išleistoje knygoje apie M. Sleževičių ${ }^{4}$. Joje M. Sleževičiaus veikla Pirmojo pasaulinio karo metais aprašyta fragmentiškai.

Pažymėtina, jog išeivijoje autoriai susidūrè su didele problema pagrindinių šaltinių trūkumu. Jie liko okupuotoje Lietuvoje. Dèl šios

3 Būtėnas, J., Mackevičius, M. Mykolas Sleževičius: Advokatas ir politikas. Vilnius, 1995, p. 6-8.

4 Mykolas Sleževičius: [straipsnių rinkinys] / Butėnas J., Mackevičius M., Škirpa K., Valuckas A., Novickienė B., Kardelis J., Novickis A., Šmulkštys L., Bildušas J., Audènas J., Mikuckis J. Chicago, 1954. 
priežasties išeivijoje ištirti M. Sleževičiaus politinę veiklą buvo neįmanoma. Galbūt todèl apie šią asmenybę rašyta daugiau atsiminimų forma. Pirmiausia tai pasakytina apie minètą autorių kolektyvo knygą, su menkais pakeitimais perleistą po Lietuvos nepriklausomybès atkūrimo ${ }^{5}$. Knygos autoriai - valstiečiai liaudininkai, išvien veikę su pagrindine aprašoma asmenybe. Svarbiausia, buvę M. Sleževičiaus bendraminčiai pernelyg sureikšmino šio politiko indèlị $\mathfrak{t}$ aprašomus Lietuvos politinius ịvykius. Tą patị galima pasakyti ir apie išeivijoje valstiečių liaudininkų leistus periodinius leidinius „Sèja“ ar „Varpas“, kurių proginiai numeriai būdavo skiriami 1939 m. mirusiam M. Sleževičiui. Objektyvumo pasigendama ir valstiečių liaudininkų veikèjo paskutinio nepriklausomos Lietuvos žemès ūkio ministro Juozo Audèno knygoje apie valstiečius liaudininkus. J. Audènas epizodiškai aptarè ir M. Sleževičiaus vaidmenị Pirmojo pasaulinio karo metais bei minètoje partijoje ${ }^{6}$. Objektyvumo trūksta ir išeivijoje išleistoje Jurgio Gliaudos knygoje „Sunkiausiu keliu“ (Chicago, 1973), kurioje daugiausia dèmesio skirta M. Sleževičiaus politinei veiklai nepriklausomybès pradžioje ginant Lietuvą nuo išorès priešų.

SSRS okupuotoje Lietuvoje M. Sleževičiaus veikla nesulaukè atskiro tyrimo. Istorija buvo klastojama, ir bet kokie objektyvesni tyrimai, ypač susiję su 1918-1940 m. Lietuva, tiesiog buvo neịmanomi. Iš išliekamąją vertę turinčių darbų, kuriuose minimas ir politikas M. Sleževičius, galima išskirti autorių kolektyvo darbą apie politines partijas Lietuvoje 1919-1926 m. ${ }^{7}$ Tuo tarpu M. Sleževičiaus ankstesnè politinė veikla dèmesio nesulaukè.

Atkūrus Lietuvos nepriklausomybę, atsivèrus istorijos archyvams, pradèti Lietuvos politinio elito tyrimai. Taip atsirado darbų

Būtėnas, J., Mackevičius, M. Mykolas Sleževičius: Advokatas ir politikas. Vilnius, 1995.

6 Audènas, J. Lietuvos valstiečiai liaudininkai. Brooklyn, New York, 1982.

7 Noreikienè, S. Lietuvos valstiečių liaudininkų sajunga. Klasés ir politinés partijos Lietuvoje 1919-1926 metais. Vilnius, 1978, p. 74-87 ir kt. 
apie M. Sleževičiaus kaip ministro pirmininko ${ }^{8}$ bei užsienio reikalų ministro veiklą ${ }^{9}$, jo parlamentinę veiklą ${ }^{10}$. Atskiri M. Sleževičiaus politinès veiklos epizodai aptarti ir daugelyje kitų istorikų knygų. Reikia paminèti istorikų Egidijaus Motiekos darbą apie Didịji Vilniaus Seimą ${ }^{11}$, Rimanto Miknio ${ }^{12}$ knygą apie Lietuvos demokratų partiją, Raimundos Lopatos ${ }^{13}$ knygą apie Lietuvos politikų veiklą Pirmojo pasaulinio karo metais, Alfonso Eidinto ${ }^{14}$ knygas apie Lietuvos prezi-

8 Čepas, R. Ministras pirmininkas Mykolas Sleževičius. Lietuvos Respublikos Ministrai Pirmininkai 1918-1940. Vilnius, 1997, p. 71-117.

9 Kasparavičius, A. Mykolo Sleževičiaus profilis tarpukario Lietuvos užsienio politikoje (1919 04 12-10 06 ir 192606 15-12 16). Lietuvos užsienio reikalų ministrai 1918-1940. Kaunas, 1999, p. 197-225.

${ }^{10}$ Stakeliūnaitè, D. Liaudininkai koaliciniuose žaidimuose $(1918 \mathrm{~m}$. gruodis-1919 m. spalis). Darbai ir dienos, 1998, t. 7, p. 121-140; Stakeliūnaite, D. 1926 m. gruodžio 17 d. perversmo padarinių legalizavimas: Lietuvos valstiečių liaudininkų sajungos vadovybès pozicija. Istorija, Vilnius, 1999, XLI, p. 34-39; Stakeliūnaitè, D. Valstiečiai liaudininkai Steigiamajame seime (1920 06 19-1922 02 02): tarp koalicijos ir opozicijos. Politikos moksly almanachas, 2010, t. 7, p. 35-62; Stakeliūnaitè, D. Valstiečiai liaudininkai Lietuvos Respublikos vidaus politikoje 1918 m. pabaigoje-1926 m.: parlamentiné veikla. Daktaro disertacija. Humanitariniai mokslai, istorija (05 H). Kaunas, 2000, Lietuvos nacionaliné biblioteka rankraščiu skyrius, f. 132-1469; Stakeliūnaite, D. Sleževičius Mykolas. Lietuvos Steigiamojo Seimo (1920-1922 metu) nariu biografinis žodynas. Sudare A. Ragauskas, M. Tamošaitis, (Didysis Lietuvos parlamentarų biografinis žodynas, t. 2). Vilnius, 2006, t. 2, p. 336-341; Stakeliūnaitè, D. Sleževičius Mykolas. Lietuvos Respublikos I Seimo (1922-1923 metu), II Seimo (1923-1926 metu), III Seimo (1926-1927 metu) ir IV Seimo (1936-1940 metu) nariu biografinis žodynas. Sudare A. Ragauskas, M. Tamošaitis), Didysis Lietuvos parlamentarų biografinis žodynas, t. 3. Vilnius, 2007, t. 3, p. 467-474; Stakeliūnaitè, D. Ministras pirmininkas Kazys Grinius valstiečių liaudininkų vidaus nesutarimų kontekste (1920 m. gegužè-1921 m. spalis). Parlamento studijos, 2016, nr. 21, p. 31-56.

${ }^{11}$ Motieka, E. Didysis Vilniaus Seimas. Vilnius, 2005.

${ }_{12}$ Miknys, R. Lietuvos demokratų partija 1902-1915 metais. Lietuviu atgimimo istorijos studijos, t. 10. Vilnius, 1995.

${ }^{13}$ Lopata, R. Lietuvių inteligentijos politinè veikla 1914-1915 metais. Lietuviu atgimimo istorijos studijos, t. 3. Vilnius, 1996.

${ }^{14}$ Eidintas, A. Antanas Smetona ir jo aplinka. Vilnius, 2012; Eidintas, A. Aleksandras Stulginskis ir jo epocha. Vilnius, 2014. 
dentus Antaną Smetoną ir Aleksandrą Stulginskį, Artūro Svarausko ${ }^{15}$ apie Lietuvių krikščionių demokratų partiją, Sandros Grigaravičiūtès apie Lietuvos Tarybos atstovavimą Sovietų Rusijoje 1918 m. ${ }^{16}$, kuriose daugiau ar mažiau bendroje to meto politineje panoramoje atskleidžiami ir M. Sleževičiaus veiksmai.

Išanalizavus gausią istoriografiją, galima konstatuoti, jog M. Sleževičiaus politinè veikla ankstyvuoju laikotarpiu (iki Lietuvos nepriklausomybės atkūrimo 1918 m.) iki šiol nesulaukè dėmesio arba pristatyta tik fragmentiškai aptariant kitų objektų tyrimus.

Baltą istoriografijos dèmę bent iš dalies užpildys šis straipsnis, kurio tikslas - ištirti M. Sleževičiaus veiklą Pirmojo pasaulinio karo laikotarpiu (1914-1918 m.).

Kad būtų pasiektas tikslas, išsikelti šie uždaviniai: 1. Ivertinti M. Sleževičiaus ịsijungimą i dešiniosios pakraipos Lietuvių draugijos nukentejjusiems dèl karo šelpti (LDNKŠ) veiklą Rusijoje; 2. Atskleisti šio politiko vaidmenị Rusijos lietuvių seime Petrograde; 3. Išanalizuoti M. Sleževičiaus poziciją per Lietuvos socialistų liaudininkų partijoje vykusius nesutarimus; 4. Išryškinti M. Sleževičiaus veiklą Vyriausioje lietuvių taryboje Rusijoje; 5. Aptarti M. Sleževičiaus požiūrị i Lietuvos nepriklausomybès perspektyvas $1918 \mathrm{~m}$. pradžioje.

Rašant straipsnị naudoti šie tyrimo metodai: aprašomasis, analizès, sintezès.

Kad būtų lengviau orientuotis aprašomuose ịvykiuose ir naudojamuose šaltiniuose, straipsnyje datos pateikiamos senuoju stiliumi, o draugijų (organizacijų) pavadinimai - kaip „Visuotinėje lietuvių enciklopedijoje“, tik citatose ir šaltiniuose - kaip buvo ịprasta nagrinėjamu laikotarpiu. Tačiau istorikų darbuose ir kitokio pobūdžio literatūroje datos pateiktos pagal naująji stilių (tarp abiejų laiko skai-

15 Svarauskas, A. Krikščioniškoji demokratija nepriklausomoje Lietuvoje (19181940 m.): politine galia ir jos ribos. Vilnius, 2014.

${ }^{16}$ Grigaravičiūtè, S. Lietuvos Tarybos atstovavimas Sovietų Rusijoje 1918 metais. Parlamento studijos, 2017 m., Nr. 23, p. 11-44. 
čiavimo stilių - dviejų savaičių intervalas). Norint išvengti painiavos, nuspręsta datas palikti kaip figūruoja šaltiniuose ir istorikų darbuose.

Šaltinių apžvalga. Rengiant straipsnị daugiausia remtasi gausia nagrinèjamo laikotarpio periodine spauda: „Lietuvos žiniomis“, „Lietuvos ūkininku“, „Naująja Lietuva“, „Lietuvių balsu“, „Vadu“, „Komunistu“ ir kt. Tyrimui labai padejo publikuoti šaltinių leidiniai, tarp jų - Lietuvos Tarybos posėdžių protokolai ${ }^{17}$, Petro Klimo dienoraštis $^{18}$. Daug medžiagos gausiuose aprašomų ịvykių atsiminimuose ${ }^{19}$. Taip pat straipsnyje panaudoti minètų ir kitų istorikų darbai.

\section{Lietuvių draugijoje nukentẻjusiems dẻl karo šelpti}

1914 m. rugpjūtị kilęs Pirmasis pasaulinis karas sukrètė Lietuvą. Carinè Rusija, rengdamasi karui su Vokietija, pradejjo skubią mobilizaciją, rekvizuoti arklius, vežimus ir ypač rusų kariuomenei reikalingą maistą. Padètis Lietuvoje darèsi sudètinga. „Dar nematyti karo galo, o jo skaudi letena jau užgule beveik visą mūsų kraštą, neaplenkdama nei varguolio grịčios, nei lobininko rūmų. Jau pusė Lietuvos guli išgriauta, kita gi - bailiai dairosi ir kasdien laukia nelaimės užgriūvant“, - 1915 m. vasarą rašè „Lietuvos žinios“20. Dèl karo veiksmų iš pagrindų pablogejo gyventojų padètis, atsirado daug pabėgèlių.

Reaguodami ì sudètingą padètị karo pradžioje, Vilniuje ịvairių partijų atstovai ịkūrẻ Lietuvių politikos centrą, jis daug dèmesio skyrè karo problemoms ir Lietuvos ateities klausimams. Lietuvių politikos centras pirmiausia stengèsi pagelbėti nuo karo nukentejjusiems Lietu-

${ }_{17}$ Lietuvos Taryba ir nepriklausomos valstybès atkūrimas 1914-1920 metu dokumentuose. Sudarè A. Eidintas, R. Lopata. Vilnius, 2017.

18 Klimas, P. Dienoraštis. Chicago, 1988.

19 Pvz., Skipitis, R. Nepriklausomą Lietuvą statant: atsiminimai. Chicago, 1961; Yčas, M. Atsiminimai. Nepriklausomybès keliais. Antroji laida. Chicago, 1991, t. II ir kt.

${ }^{20}$ Lietuvių Draugijos nukentejusiems dèl karo gyventojams agronomijos ir teisių pagalbai teikti Valdyba. Lietuvos visuomenei. Lietuvos žinios. 1915, birželio 10 (Nr. 65), p. 1. 
vos gyventojams. Tuo tikslu nuspręsta steigti draugiją. 1914 m. lapkričio viduryje buvo įregistruoti Lietuvių draugijos nukentejjusiems dèl karo šelpti (LDNKŠ) įstatai. Draugijos steigejjai: pris. adv. Petras Leonas, Rusijos Dūmos atstovas Martynas Yčas, Antanas Smetona, Emilija Vileišienė, d-ras Antanas Vileišis, kun. Konstantinas Olšauskas ir inž. Jonas Mašiotas ${ }^{21}$. Gruodžio 7 d. ịvykusiame susirinkime draugijos pirmininku išrinktas M. Yčas, o vicepirmininkais - A. Smetona ir kun. Juozapas Kukta ${ }^{22}$. Žvelgiant per ideologinę prizmę - valdybos daugumą sudaré dešiniųjų pažiūrų, nors susirinkime dalyvavo ir kairiosios ideologijos atstovų. Tarp jų ir M. Sleževičius, kuriam „susirinkimas darè nemalonų ịspūdị". Jam ị akis kliuvo auditorijos sudètis („čia buvo mažne visa Vilniaus lietuvių inteligentija, vietiniai bei kauniškiai kunigai ir kelios dešimties tarnaičių“), susirinkimo vedejjo netolerancija savo pažiūrų priešininkams bei „dešiniųjų aklas užsispirimas neịsileisti ị komitetą negeistinų jiems žmonių “23.

Taip atsitikus, 1915 m. pradžioje iš LDNKŠ nusprendè pasitraukti kairieji. LDNKŠ atstovas Martynas Januškevičius 1915 m. pradžioje pareiškė išstojęs iš draugijos. Pasitraukimo priežastis - „Dabartinis gi draugijos komitetas atstovauja tik klerikalų tautininkų srovę, ir visos pastangos pataisyti jo „vienąšalumą“ nuejjo ant niekų dèlei minètosios srovės užsispyrimo“24. M. Januškevičiaus pavyzdžiu iš LDNKŠ išèjo Pranas Keinys, Andrius Bulota, Jonas Vileišis, Felicija Bortkevičienė, Jurgis Šaulys, Julija Žymantienè-Žemaite, M. Sleževičius ir kiti ${ }^{25}$. Nuo šiol LDNKŠ liko vieni dešinieji, o šią draugiją palikę kairieji gegužę

${ }^{21}$ Gk. Lietuvių draugija nukentejjusiems dèl karo šelpti. Lietuvos žinios. 1914, lapkričio 21 (Nr. 182), p. 21.

${ }^{22}$ Lietuviu draugijos Centralinio komiteto nukentëjusiems dèl karo šelpti apyskaita: nuo 1914 m. lapkričio mèn. 22 d. ligi 1915 m. liepos men. 1 d. Petrapilis, 1915, p. 4.

${ }^{23}$ M. [Sleževičius M.]. „Lietuvių draugijos nukentėjusiems dèl karo šelpti“ nepaprastas visuotinas narių susirinkimas. Lietuvos žinios. 1914, gruodžio 17 (Nr. 193), p. 2.

${ }^{24}$ Iš „Lietuvių Draugijos nukentejjusiems dèl karo šelpti“. Lietuvos žinios. 1915, sausio 4 (Nr. 1), p. 2.

${ }^{25}$ Iš Lietuvių draugijos nukentejjusiems nuo karo šelpti išstojo... Lietuvos ūkininkas. 1915, (Nr. 3), p. 28-29. 
ịsteigè Lietuvių draugiją nukentejjusiems dèl karo gyventojams agronomijos ir teisių pagalbai teikti (draugija sutrumpintai vadinta Agronomų draugija). Atrodo, M. Sleževičiaus pasitraukimą iš LDNKŠ ir ịstojimą i Agronomų draugiją lèmé solidarizavimasis su kitais kairiųjų pažiūrų veikèjais.

Gegužès $21 \mathrm{~d}$. Vilniuje ịvykusiame steigiamajame šios draugijos susirinkime dalyvavo daugiau nei 40 žmonių, ịstoti ị draugiją išreiškè norą ir keli neatvykę. Susirinkime nurodytas pagrindinis draugijos tikslas - „gaivinti nukentejusius dèl karo ūkius“. Šj tikslą pasiekti draugija ketino: a) pirkdama arklius ir galvijus, b) tiekdama ūkio irrankius, c) rūpindamasi sèkla, d) ieškodama prieinamo ir pigaus kredito nukentejusiems dèl karo, e) rūpindamasi, kad pašauktųjų i karą šeimų žemè būtų dirbama, f) steigdama ūkio, vartotojų ir kredito kooperacijos įstaigas, g) steigdama vietos ūkio biurus darbininkų ir darbo ieškančiųjų „reikalams tenkinti“, suteikdama agronomijos ir teisių patarimų vietos žmonėms. Draugija veikė Vilniaus, Kauno, Gardino ir Suvalkų gubernijose ${ }^{26}$. Isteigta nauja draugija, pasak J. Vileišio, nė nemanė varžytis su LDNKŠ: esą pastaroji - daugiausia labdarybès įstaiga, kuriai rūpi teikti laikiną pagalbą nukentẻjusiesiems, o naujosios draugijos uždavinys - „sutvarkyti iširusị dèl karo ekonominị Lietuvos gyvenimą “27. Agronomų draugijos išrinktosios valdybos nariai pagal pareigas pasiskirste taip: pirmininkas J. Vileišis, pavaduotojas Steponas Kairys, kasininkas Peliksas Bugailiškis, sekretorius Jonas Kriščiūnas, jo pavaduotojas Mykolas Biržiška ${ }^{28}$. Visi jie priklausẻ LDP arba LSDP. M. Sleževičius (kartu su A. Janulaičiu) įejjo ị draugijos teisininkų komisijos sekciją bei (kartu su Juozu Pakniu) ị kooperacijos komi-

${ }^{26}$ Lietuvių draugijos nukentejusiems dèl karo gyventojams agronomijos ir teisių pagelbai teikti įstatai. Vilnius, 1915 m. LMAVB RS, f. 70-419.

27 Vanagas, J. İsteigiamasis ,Lietuvių Draugijos nukentèjusiems dèl karo gyventojams agronomijos ir teisių pagalbai teikti“" susirinkimas. Lietuvos žinios. 1915, gegužès 24 (Nr. 58), p. 1-2.

${ }^{28}$ Lietuvių Draugijos agronomijos ir teisių pagalbai teikti nukentejusiems nuo karo šelpti“ išrinktosios valdybos nariai... Lietuvos ükininkas. 1915 m., Nr. 19, p. 172. 
sijos sekcijąa ${ }^{29}$. M. Sleževičius priklausė ir draugijai „Sveikata“, veiklą pradejusiai $1915 \mathrm{~m}$. gegužę. ${ }^{30}$

Kaip matome, $1915 \mathrm{~m}$. Lietuvoje veikè dvi panašaus pobūdžio draugijos, kurių sudètis ideologiškai skyrėsi. Abiejų draugijų veikla pasunkėjo Lietuvos teritoriją palikus Rusijos karinems pajegoms. 1915 m. rugsèjo 5 d. išèjusiame paskutiniame "Lietuvos žinių“ numeryje skaitytojams buvo pranešta, kad tą dieną iš Vilniaus pasitraukè rusų kariuomenè. „Vilnius - Lietuvos širdis, senovés lietuvių sostinè. Netrukus miestan įeis vokiečių kariuomenè. Lietuvoje atsiveria naujas gyvenimo lapas. Koksai bus tas gyvenimas, tuo tarpu ne laikas dar spręst. Laikykimès vienybėje, visai ramiai, be jokių išsišokimų, kaip pridera seniausiems miesto piliečiams ${ }^{\text {“31. }}$. Rusijos priespaudą pakeitė prasidejusi Vokietijos okupacija.

Pakitusiomis sąlygomis M. Yčui ir daliai LDNKŠ narių pasitraukus ị Rusiją (draugijos pirmininku Lietuvoje tapo A. Smetona), draugija, šelpdama vietos lietuvius, atliko milžinišką darbą (karo pabaigoje Rusijoje veikè apie 250 draugijos skyrių ${ }^{32}$ ). I šios organizacijos veiklą ísijungè ir M. Sleževičius, tuo metu su žmona pasitraukęs ị Rusiją. Kaip atsiminimuose nurodo šios organizacijos (kitur nurodomas komitetas) pirmininkas M. Yčas, iš pradžiu M. Sleževičius buvo ịstojęs ị „Visos Rusijos Zemstvų organizaciją bei Obyvatelių Komitetą, bet kaip geras lietuvis ir patriotas, matyti, jaute pareigą dirbti lietuviams“. İkalbètas Stasio Šilingo M. Sleževičius įsijungè ị LDNKŠ. Apie tai M. Yčas atsiminimuose rašo: „Nelengvas, matyti buvo toks persilaužimo momentas, bet jis ji nugalèjo. (...). Jis iejejo ị mano kabinetą šiek tiek sujaudintas ir drebančiu balsu pasaké:

${ }^{29}$ Iš Liet. agron. ir teisių pagalbai teikti draugijos. (Valdybos posedyje birželio 5 d.). Lietuvos žinios. 1915, birželio 7, (Nr. 64), p. 4.

${ }^{30}$ Smetona, A. Sveikatos ir Agronomijos bei teisininkų draugijos. Vairas. 1915 m., Nr. 18, p. 281-282.

31 Naujas gyvenimo lapas. Lietuvos žinios. 1915, rugsèjo 5, p. 1.

32 Čepėnas, P. Naujujų laiku Lietuvos istorija. Fotografuotinis leidimas. Vilnius, 1992, t. II, p. 47. 
- Štai, pone pirmininke, ir aš atejjau pas Tamstą dirbti.

- Man labai malonu Tamstą pasveikinti, bet aš norèčiau Tamstos žodžius pataisyti, būtent ne pas ma n e, bet pas $\mathrm{m}$ u $\mathrm{s}$ ir $\mathrm{s}$ a ve. Mes visi čia dirbame s a v o t a u t o s gelbejjimo darbą... Tenka tik pasidžiaugti, kad C. Komitetas susilaukia vis daugiau darbininkų “33.

Taigi nors M. Sleževičius buvo kairiųjų pažiūrų ir prieš karą kritikavo patị M. Yčą, jis sutiko užimti ypatingojo Pietų Rusijai igaliotinio vietą. Jis $1916 \mathrm{~m}$. vasarị Petrograde lietuvių suvažiavime ilgoje kalboje aptarè sunkią lietuvių padètị Pavolgio regione ${ }^{34}$. Voroneže publikuotame leidinyje $\mathrm{e}^{35}$, adresuotame LDNKŠ CK, M. Sleževičius pateikè ataskaitą apie šios draugijos igaliotinio Jaroslavlyje kunigo Gustaičio ir jo skyriaus veiklą (ją M. Sleževičius revizavo 1917 m. spalị ir gruodị). M. Sleževičiaus „darbuotė“, M. Yčo teigimu, buvo „labai naudinga; jis daug prisidejo prie kontroliavimo ir įvedimo tvarkos îvairiuose skyriuose bei įstaigose. Komitetas jo darbuotę visuomet aukštai vertindavo“36. „Jis kontroliavo skyrius bei igaliotinius ir daug prisidejo prie atskaitymybès sutvarkymo. Einant savo tarnybą, jam dažnai tekdavo susidurti su įvairiais organizacijos netobulumais ir iškelti prieš C. Komitetą kai kuriuos nemalonius igaliotinių darbus. Nors kiti jo partijos nariai buvo griežtai nusistatę prieš C. K., jis tačiau niekados nenaudojo savo tarnyboje susektų paslapčių partiniams tikslams. Atsimenu, pas vieną ígaliotinị kun. B. surado kompromituojantį dokumentą - suklastotą parašą sąskaitoje (...). Jis tą dokumentą atvežè mums ị C. Komitetą ir ịteikè prezidiumui, tačiau niekas iš jo partinių draugų nesužinojo apie tą pikantišką dokumentą. Šitas skandalingas dokumentas veikiausiai būtų buvęs "Naujosios Lietuvos“

33 Yčas, M. Atsiminimai. Nepriklausomybès keliais. Antroji laida. Chicago, 1991, t. II, p. 121-122.

34 Spaknys. Lietuvių suvažiavimas. Vadas. 1916, kovo 15, p. 8-9.

35 Tremtiniai Rusijoj ir ju globejjai. Oficialūs M. Sleževičiaus pranešimai Centro Komitetui l.d.n.d.k.š. Voronežas, 1918.

36 Yčas, M. Atsiminimai. Nepriklausomybès keliais. Antroji laida. Chicago, 1991, t. II, p. 141-142. 
skiltyse stambiausiomis raidėmis paskelbtas, jei ne Mykolo Sleževičiaus diskrecija“"37.

Kad M. Yčo išsakyti žodžiai teisingi, liudija ypatingojo igaliotinio M. Sleževičiaus parengtos išsamios ataskaitos apie jo vizituotų LDNKŠ skyrių veiklą. Ataskaitos buvo skirtos LDNKŠ vadovybei, t. y. ne viešai naudoti. Tačiau suėmus Vyriausiosios lietuvių tarybos Rusijoje (VLTR) narius bei perėmus jos dokumentus, tarp kurių buvo ir M. Sleževičiaus rašytos ataskaitos, jos atsidūrẻ komunistų rankose. Kadangi LDNKŠ igaliotinis savo ataskaitose aprašè ir negatyvius LDNKŠ skyrių ir narių darbus, tai dabar komunistams atsirado puiki galimybè tai paviešinti, siekiant tik negatyviai nušviesti LDNKŠ veiklą. Lietuvos komunistų partijos (LKP) lyderis Zigmas Aleksas Angarietis didelę dalị M. Sleževičiaus ataskaitų ištraukų apie LDNKŠ pateikè Voroneže leistame periodiniame leidinyje „Komunistas“"38.

Iš M. Sleževičiaus ataskaitų paaiškèja, kad Rusijoje veikusiuose LDNKŠ skyriuose būta didelių problemų, sunkumų, ypač ị akis krito jų skyrių vadovybės nesąžiningumas skirstant draugijos lèšas bei naudojantis turtu. Dèl to draugijos skyrių kasos knygos buvo vedamos neteisingai ar visai nepildomos. Dažnai ataskaitose minimi netaktiški skyrių vadovybès santykiai su pavaldiniais bei tremtiniais. Kaip pavyzdi galima paminèti M. Sleževičiaus ataskaitos ištrauką apie Rostovo prie Dono skyriaus veiklą: „Kasos knygos nuo lapkričio iki 31 gegužès d. buvo vedamos dideliausioj betvarkèj. Daug vietų užbraukyta, daug i̇rašyta, daug skaitlinių pataisyta; sumos netinkamai pamuštos; ištisi puslapiai išbraukyti“. „Materialè knyga... iki šiol nevedama... O nèra materialès knygos, iš kurios galima būtų patikrinti tikrasai dalykų stovis“, „Apsiejjimas su tremtiniais labai šiurkštus“.

37 Yčas, M. Rusijos lietuvių pastangos kovose už Lietuvos nepriklausomybę. Pirmasis nepriklausomos Lietuvos dešimtmetis. Kaunas, 1990, p. 21-33.

38 Angarietis, Z. Žmonių geradèjai. Komunistas. 1918 m., Nr. 7, p. 51-52; Nr. 8, p. 57-58; Nr. 9, p. 70-71; Nr. 12, p. 97-98; Nr. 13, p. 107; Nr. 14, p. 113-114; Nr. 15, p. 122-123; Nr. 16, p. 129-130. 
Net po keturių mėnesių antrą kartą atvykęs ị Rostovo prie Dono sky-

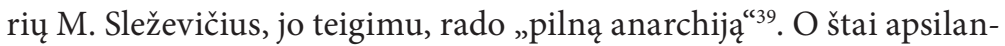
kęs Simbirske 1916 m. liepos 20 d. jis labai kritiškai ịvertino LDNKŠ vietos skyriaus vadovo Avižonio bendravimą su aplinkiniais. Pastarasis esą „priversdavo žmones po kelias dienas lankytis ị kanceliariją, visą dieną ten išstovèti, tik po 3-5 valandų stovejjimo pasakydavo žmonèms, kad jie rytdieną ateitų. - ir vėl tas pats pasikartodavo“" Tokių ir panašių negerovių gausu M. Sleževičiaus parengtose ataskaitose. Iš jų matyti, kad pabėgèlių padètis buvo sudètinga ne tik dèl karo, bet ir dèl dalies LDNKŠ skyrių vadovų netinkamo darbo ir santykių su pavaldiniais bei Rusijoje atsidūrusiais tèvynainiais. Tuo tarpu, kaip matyti iš surašytų ataskaitų, jų autorius M. Sleževičius, besirūpindamas lietuvių pabėgèliais, apkeliavo didelę dalị Rusijos teritorijos, vizitavo daug LDNKŠ skyrių ir, būdamas labai ịsigilinęs ị pabėgèlių problemas, kiek leido to meto sudetingos sąlygos prisidèjo prie LDNKŠ veiklos gerinimo.

\section{Rusijos lietuvių seime Petrograde}

1915 m. Lietuvą okupavusi Vokietija uždraude bet kokią politinę veiklą Lietuvos teritorijoje. Todèl lietuvių ir kitų svetimos valdžios kontroliuojamų tautų atstovams tinkamiausia vieta laisviau išsakyti politines nuostatas tapo neutrali Šveicarija ar Švedija. Čia per karą keliose konferencijose lietuviai pasisakè už Lietuvos nepriklausomybę. Tokių pat tikslų siekè ir JAV lietuviai.

Padètis keitèsi ir Rusijoje, ị kurią karo pradžioje iš Lietuvos pasitraukẻ apie 300 tūkst. lietuvių. Iš pradžių vietos lietuviai buvo už Lietuvos autonomiją Rusijos sudètyje. O dar karo pradžioje „gintarinès deklaracijos“ autoriai (Jonas Basanavičius, Donatas Malinauskas) visos lietuvių tautos vardu pasisakè už paramą Rusijai, pabrèždami: „isto-

39 Angarietis, Z. Žmonių geradejjai. Komunistas. 1918 m., Nr. 12, p. 97-98.

${ }^{40}$ Angarietis, Z. Žmonių geradejai. Komunistas. 1918 m., Nr. 14, p. 113. 
rinė Rusijos misija - būti tautų išlaisvintoja" ${ }^{41}$. Bet 1917 m. pradžioje padètis iš esmès pasikeitè. Ivykus Vasario revoliucijai, vietos lietuvių periodiniame leidinyje „Naujoji Lietuva“ pačiame viršuje po pavadinimo pateiktas užrašas, atspindintis to meto lietuvių tautos lūkesčius: „Sutrupo vergijos retežiai. Rusija nusikratė sauvalių despotų Romanovu jungo. Tegyvuoja revoliucija! Tegyvuoja laisva demokratinė Rusijos tautų federacija!“42 „Naujosios Lietuvos“ vedamojo straipsnio autoriaus supratimu, ịvykiai Rusijoje suvokti, kaip „visiška taip lietuvių taip ir kitų tautų politinio apsisprendimo laisve் ${ }^{\text {“43 }}$.

Naujomis sąlygomis Rusijoje lietuvių politikai ėmė aktyviau, svarbiausia, ir legaliai veikti. Veiklą atgaivino ar naujai ịsikūrẻ lietuvių politinès partijos ${ }^{44}$. Ta proga vasario $11 \mathrm{~d}$. Rusijos sostineje Petrograde (lietuvių vadinamame Petrapiliu) įvyko įvairių lietuvių srovių susirinkimas. Jame buvo pasiūlyta bendra trijų partijų - Demokratinès tautos laisvès santaros, socialdemokratų ir socialistų liaudininkų - rezoliucija, kurioje, be kita ko, buvo sakoma: „Manydami, 1) kad vienintelis Lietuvių Tautos tikslas tegali būti - laisvès ịsigijimas savo likimui spręsti; 2) kad Lietuvių Tautai Laisvès ịsigijimas tegalimas tik nuolatinio, organizuoto politinio darbo keliu, kuriuo būtų nuoseklia, viso pasaulio tautoms reiškiama Lietuvių Tautos valia, - skaito reikalinga sudaryti tam tikrą autoritetingą organą, būtent - Lietuvių Tautos Tarybą" “45.

Po dviejų dienų ívykusiame steigiamajame Lietuvių tautos tarybos (LTT) posėdyje iš kiekvienos lietuvių partijų buvo išrinkta po tris atstovus, tarp jų iš socialistų liaudininkų: Petras Balys, P. Bakanauskas ir Vaclovas Bielskis ${ }^{46}$. Kaip matyti, tuo metu tarp socialistų liaudi-

${ }^{41}$ Lietuvos Taryba ir nepriklausomos valstybès atkūrimas 1914-1920 metų dokumentuose. Sudarė A. Eidintas, R. Lopata. Vilnius, 2017, p. 122.

42 Naujoji Lietuva. 1917, kovo 11, p. 1.

${ }^{43}$ Caro vyriausybę nuvertus (vedamasis). Naujoji Lietuva. 1917, kovo 11, p. 1.

${ }^{44}$ Grigaravičius, A. Politinių pabėgėlių veikla Rusijoje 1917 metais. Darbai ir dienos. 2013 , t. 60 , p. 23-72.

45 Tautos Taryba. Naujoji Lietuva. 1917, kovo 19, p. 2.

46 Ten pat. 
ninkų didesnị svorị turejjo Rusijos sostinejje veikę minėti šios partijos nariai. Antai kovo 26 d. Lietuvos demokratų (socialistų-liaudininkų) partijos Petrogrado srities steigiamajame susirinkime ì Petrogrado srities valdybą išrinkti: V. Bielskis, M. Januškevičius, P. Balys, P. Bakanauskas ir B. Matulionis, o kandidatais - O. Puodžiūnaitė ir J. Bartašius. Tuo tarpu renginị atidaręs ir kartu su F. Bortkevičiene padaręs partijos veiklos apžvalgą $M$. Sleževičius tebuvo išrinktas tik i̇ partijos literatūros komisiją. I partijos vadovybę taip pat nebuvo išrinkta ir F. Bortkevičienè; kartu su dar keliais nariais ji ièjo ị literatūros ir finansų komisijas ${ }^{47}$. Tuo metu buvę LDP senbuviai F. Bortkevičienè ir M. Sleževičius buvo nustumti ị antrą planą ir partijos vairą i savo rankas paèmė kiti asmenys. Pažymėtina, kad tuo metu dar veikè viena partija - LSLP, kuriai priklausė visi minèti asmenys tarp jų - F. Bortkevičienė ir M. Sleževičius. Jie kartu atstovavo ir Rusijos lietuvių seime Petrograde (RLSP) 1917 m. gegužès pabaigoje-birželio pradžioje.

Dèmesio vertas epizodas: dar $1917 \mathrm{~m}$. kovo $13 \mathrm{~d}$. LTT sudarè Laikinąji Lietuvos valdymo komitetą, kuris balandžio $20 \mathrm{~d}$. ir $26 \mathrm{~d}$., svarstydamas Lietuvos valdymo klausimą, be kita ko nutare pristatyti Laikinajai Rusijos vyriausybei (vadovaujamai G. Lvovo), kad ji paskirtų Kauno gubernijos komisaru „pilietị, prisiekusi advokatą Mykolą Sleževičių “48. Numatymas M. Sleževičių skirti ị tokias aukštas pareigas leidžia kalbèti apie jo, pirmiausia kaip teisininko, autoriteto pripažinimą. Tačiau jam neteko eiti minėtų pareigų, nes laikinoji Rusijos vadovybė rimtai nežiūrèjo ị Laikinąji Lietuvos valdymo komitetą. Todèl i jo prašymą nebuvo reaguota.

Tiesa, iš Petro Klimo dienoraščio paaiškejja, jog Lietuvoje buvo paskleista kiek kitokia žinia: Rusijoje Vilniaus gubernatoriumi esąs paskirtas M. Sleževičius, o Suvalkų gubernatoriumi - Kazys Grinius.

${ }^{47}$ Krikščiūnas, J. Lietuvos Demokratų (Socijalistų-Liaudininkų) Partijos Petrapilio srities Steigiamasai susirinkimas. Naujoji Lietuva. 1917, kovo 31, p. 1.

${ }^{48}$ Pirmininkas baronas Šilingas S., sekretorius Noreika L. Laikinojo Lietuvos Valdomojo Komiteto pirmieji darbai. Lietuvių balsas. 1917, gegužès 25 (Nr. 36), p. 1. 
Tokia žinia buvo sutikta juokais, kad „Rusijos lietuviai vis dar apie "gubernatorius“" tesvajoją. Rasi ir jie iš rusofilų kiauto kada išsiners..." ${ }^{49}$ Kaip matyti, tėvynèje gyvenę lietuvių politikai tuo metu kitaip suvokè savo šalies perspektyvas nei Rusijoje veikę tėvynainiai, pernelyg daug dejję vilčių i šią valstybę.

Ideja šaukti lietuvių seimą tuometeje Rusijos sostineje kilo LTT (pirmininkas S. Šilingas). Rinkimai numatyti 1917 m. gegužès pabaigoje. Atstovus į Seimą galejo rinkti visi Rusijoje gyvenantys lietuviai, neišskiriant karininkų, vyrai ir moterys, sulaukę 18 metų. Vieną atstovą turejjo rinkti 200 lietuvių. Mažesnèse kolonijose vieną asmeni galejo rinkti nuo 50 iki 200 lietuvių. Pagal numatytą tvarką balsavimas turejo būti tiesioginis, lygus ir slaptas. LTT atsišaukime buvo kviečiami atstovai atvykti ị Seimą - „kurti Laisvos Demokratinès Lietuvos“ ${ }^{\text {“50. }}$.

I gegužès pabaigoje - birželio pradžioje dirbusị RLSP atvyko 334 atstovai, tačiau tik 320 atstovų mandatai buvo pripažinti galiojančiais. Seimo atstovai pagal partinę priklausomybę buvo pasiskirstę taip: socialistų liaudininkų - 90 atstovų, krikščionių demokratų - 41, socialdemokratų - 39, katalikų tautininkų - 32, Santaros - 30, Tautos pažangos - 20, nepartinių - 51, bolševikų $-2^{51}$. Kaip tiksliai pastebejjo Augustinas Voldemaras, Petrograde geriausiai buvo susiorganizavę socialistai liaudininkai, todèl nenuostabu, kad jie ir laimèjo daugiausiai vietur ${ }^{52}$.

Gegužès 29 d. posėdyje po didelių diskusijų priimtas socialistų liaudininkų siūlymas rinkti ỉ prezidiumą iš visų keturių partijų po tris žmones, kad po vieną galètų dalyvauti pačiame prezidiume, o po du sekretoriate. Išrinkti LSDP atstovai Smolskis, Rasikas, Čiurlys, socialistai liaudininkai V. Bielskis, Vaitiekūnas, Serbenta, Santaros -

${ }^{49}$ Klimas, P. Dienoraštis. Chicago, 1988, p. 156.

${ }^{50}$ Lietuvių Tautos Taryba. Visiems Rusijos lietuviams. Naujoji Lietuva. 1917, balandžio 29, p. 2.

${ }^{51}$ Čepenas, P. Naujausiuju laiku Lietuvos istorija. Vilnius, 1992, II tomas, p. 66.

${ }^{52}$ Voldemaras, A. Petrapilis. Gegužès 25 d. Ką parodè rinkimai Seiman Petrapilyje? Lietuviu balsas. 1917, gegužèd 25 (Nr. 36), p. 1. 
S. Šilingas, Burba, A. Vokietaitis, Tautos pažangos - A. Voldemaras, Blynas, Bužinskis. Iš jų i Seimo prezidiumą išrinkti Smolskis, V. Bielskis, Šilingas ir A. Voldemaras. Kiti liko sekretoriate ${ }^{53}$.

Kaip matome, M. Sleževičius nebuvo išrinktas ị Seimo prezidiumą kaip socialistų liaudininkų atstovas, nors Seime socialistai liaudininkai turèjo daugumą. Galejo ịtakos turèti ir tai, jog M. Sleževičius i RLSP atvyko kiek vẻliau nei kiti jo frakcijos nariai ${ }^{54}$. Sprendžiant iš išlikusios informacijos, RLSP iš socialistų liaudininkų aktyviausiai reiškèsi P. Balys ir M. Januškevičius. Kaip paaiškejjo iš pasisakymų RLSP, minèti socialistų lyderiai turèjo savitą požiūrị i Lietuvos ateitị. M. Januškevičius savo kalboje priejo išvadą, jog Lietuva dar negali reikalauti nepriklausomybės, tik apsisprendimo teisès. Toks M. Junuškevičiaus pasisakymas labai nustebino susirinkusiuosius ${ }^{55}$.

Tame pačiame gegužès 31-osios vakaro RLSP posėdyje tuoj po M. Januškevičiaus kalbėję J. Tumas, M. Sleževičius ir A. Voldemaras išsakè kitokią nei $\mathrm{M}$. Januškevičiaus poziciją dèl Lietuvos ateities. J. Tumo supratimu, „laisvoj Rusijoj gimè laisva, nedidelè lietuvių demokratija, nes Rusijos revoliucinè visuomenè paskelbẻ laisvès obalsi. Tik lenkai dar nenori išsižadèti Lietuvos, jie jos nepripažįsta. (...). Vokiečiai Lietuvos nebeatiduos. (...). Jie ị lietuvius žiūri kaip ne visai ì civilizuotą tautą. Visai kita būtų, jeigu Lietuva gautų nepriklausomybę. (...). Troškimas lietuviuose laisvès jau seniai augo. Rusų tik valdžia nedavè lietuviams nei pajudèti. (...). Jeigu pas mus yra obalsis nepriklausomybè, tai mes ir turim ji visur patys kelti. Jokia demokratija, pati atẻjusi, nepasakys: šia jums lietuviai nepriklausomybè ${ }^{\text {“56 }}$.

Po J. Tumo kalbejjęs M. Sleževičius, priminęs DVS, nurodė, kad jau ir tuomet buvo pasakyta, kad Lietuva turi būti laisva, lietuviai patys

53 Rgn. Rusijos lietuvių Seimas. Gegužès 29 d. posėdžio aprašymas. Lietuvių balsas. 1917, birželio 22, p. 2.

54 Sugintas, A. Bendrojo darbo bare. Sejja, 1969 m., Nr. 4, p. 45.

${ }_{55}$ Rusijos Liet. Seimas. Trečioji diena 29 geg. Vadas. Birželio 11, p. 110.

56 Pr. T. Rusijos Lietuvių Seimas. Lietuvių balsas. 1917, birželio 4, p. 1. 
privalo spręsti savo likimą. Jo teigimu, karo metu dar aiškiau iškilo tas laisvès šūkis, nes ir kariaujančios valstybės, norėdamos pritraukti prie savęs mažąsias tautas, pasiskelbẻ kariaujančios už prispaustąsias tautas. Tas „mestas šūkis rado miniose derlingą dirvą“. Nors po Vasario revoliucijos naujoji Rusijos valdžia deklaravo demokratines nuostatas, M. Sleževičius vis dèlto atsargiai vertino Rusiją: „Bet ir laisvę reikia giliau suprasti. Tegul bus demokratingiausias rusų steigiamasis susirinkimas, bet jeigu jis pasakys, kad jūs be mūsų negalit savo likimo spręsti, tai juk vistiek bus laisvès varžymas. Tegul tik rusams pasisektų sumušti vokiečius ir paimti kadetams viršų, gal rusai vẻl būtų monarchija“. Taip pat M. Sleževičius nesibaimino, kad atkūrus Lietuvos nepriklausomybę, joje valdžią gali paimti „konservatyviniai lietuvių elementai“, t. y. dešinieji. M. Sleževičiaus supratimu, „to bijoti nèra ko, lai kokią dešimtị metų ir viešpataus klerikalai Lietuvoje, bet per tą laiką liaudis susipras ir pati ims valdyti save“. O dèl Lietuvos ateities perspektyvų M. Sleževičius buvo ịsitikinęs, „jeigu mes statysim tik apsisprendimo obalsị, tai rusai manys, kad mes patys nežinom ko mes norim. Taigi greta to mums reikia statyti du obalsiu apsisprendimo ir nepriklausomybės. Tuomet bus aišku, ko mes norim. Lietuvos klausimas menkutis, bet jeigu mes čia esantieji ir ten Lietuvoje pasilikusieji visur šauksime ir reikalausime laisvès, kad mes patys norim savo likimą spręsti, turi mus išgirsti “57.

Po M. Sleževičiaus kalbejjęs A. Voldemaras daug tikejjosi iš karo pabaigoje didžiųjų valstybių sušaukto taikos kongreso. Manyta: kaip jame bus išspręstas Lietuvos klausimas, taip „jis pasiliks ilgam laikui“. Ir jeigu taikos kongrese bus „mesta Lietuvos nepriklausomybės ideja ir mes mokésim parodyti, kad jau esam subrendę, tuomet su mumis skaitysis“. Pasisakyta už Lietuvos neutralizavimą ir manyta, kad tada ji galètų gal kokị šimtą metų gyventi ramiai. Jis nesutiko su ta nuomone, kad lietuviai turi reikalauti apsisprendimo teisès, kad Steigiama-

${ }^{57}$ Pr. T. Rusijos Lietuvių Seimas. Lietuviu balsas. 1917, birželio 4, p. 1. 
sis Seimas pasisakytų, ko nori Lietuva. A. Voldemaras klausė: „Ar gi mūsų lauks kol mes pasakysim ko mes norim?" Esą svarbiausia, jog yra paskelbtas apsisprendimo šūkis. O mes esą apsisprendèm, kad norim nepriklausomybės. A. Voldemaro ịsitikinimu, dèl Lietuvos sienų negali būti daug ginčų, tą galès padaryti plebiscitas ${ }^{58}$.

Kaip matyti, visi trys kalbėtojai iš esmès pasisakè už nepriklausomos Lietuvos atkūrimą. Tik skyrèsi, ypač A. Voldemaro, išsakyta mintis, kokia turi būti atkurta Lietuva, pirmiausia kalbant apie saugumą. Beje, pasak M. Yčo, tuo metu M. Sleževičius buvo vienintelis iš kairiojo sparno, savo vardu nedvejodamas Seime pasisakęs už Lietuvos nepriklausomybę ${ }^{59}$.

RLSP, kuriame vyko aršūs ginčai, ypač tarp kairiųjų ir dešiniųjų partijų atstovų, pagaliau buvo pateiktos svarstyti dvi rezoliucijos. Pirmoji, priimta pažangiečių ir krikščionių demokratų, nutarė, kad „1. Visa etnografiné Lietuva privalo tapti nepriklausoma valstybé, nuolatinai neutrali. 2. Jos neutralumas privalo būti garantuotas Taikos Kongreso. 3. Taikos Kongrese turi būti Lietuvos atstovai. 4. Lietuvos valdymo būdą ir vidaus tvarką turi nustatyti sukviestas visuotiniu, lygiu ir slaptu balsavimu Steigiamasis Lietuvos susirinkimas ${ }^{\text {"60 }}$. O antroji, santariečių, socialistų liaudininkų ir socialdemokratų priimta rezoliucija skelbė: „Kreiptis ị Laikinąją Rusijos Valdžią, taip pat ị visas valstybes, sąjungininkes bei neutralias, ir reikalauti pripažint: a. kad lietuvių tautai priklauso politinio apsisprendimo teisè, b. kad savo politinị likimą lietuvių tauta turi teisę spręsti laisvai išrinktame Lietuvos Steigiamajame Susirinkime, visuotinio, be lyties, tautybės ir tikybos skirtumo, tiesaus, lygaus ir slapto balsavimo pamatais, proporcinès sistemos prisilaikant, c. kad lietuvių tauta, kaip užinteresuota tauta

58 Pr. T. Rusijos Lietuvių Seimas. Lietuvių balsas. 1917, birželio 4, p. 1.

59 Yčas, M. Rusijos lietuvių pastangos kovose už Lietuvos nepriklausomybę. Pirmasis nepriklausomos Lietuvos dešimtmetis. Kaunas, 1990, p. 30.

${ }^{60}$ Rusijos Lietuvių Seimo rezoliucija dèl Lietuvos ateities. Vadas. 1917, birželio 11, p. 109. 
turi turèti savo atstovus tarptautiniame taikos kongrese, 2 Apie visą, kas čia išdèstyta pranešti viso pasaulio demokratijoms ${ }^{\text {“61 }}$.

Kaip matyti, esminis rezoliucijų skirtumas, tad antrosios šalininkai, pasisakydami už Lietuvos nepriklausomybę, ją ateityje siejo ir su Rusijos demokratiniu judejjimu, t. y. Lietuvos klausimas ateityje turèjo būti sprendžiamas atsižvelgiant ị ịvykius Rusijoje. Pirmojoje rezoliucijoje apie tai nekalbama.

Pažymètina, kad, paaiškejjus balsavimo rezultatams, kairieji protestuodami atsistojo ir, paėmę ị rankas raudoną vẻliavą, paliko RLSP posėdžių salę. Kaip nurodo santarietis RLSP buvęs Rapolas Skipitis, „toli gražu ne visi iš seimo išejusieji atstovai norejo „eiti toliau su revoliuciniu Rusijos judejjimu“ ir ne visi buvome išèjimu patenkinti. (...) net liaudininkų (tuomet socialistų liaudininkų) žymiųjų asmenų, kaip M. Sleževičiaus ir Felicijos Bortkevičienès veiduose matėsi labai didelis nepasitenkinimas ir net ašaros akyse dèl išèjimo iš seimo“. R. Skipitis laikèsi nuomonès, kad dauguma išèjo iš Seimo tik todèl, jog pasidavè to meto nuotaikai, susidariusiai dèl per daug karštų ginčų tarp dviejų politinių grupių: pažangiečių-krikščionių demokratų bei santariečių-socialistų liaudininkų ir socialdemokratų ${ }^{62}$. Taigi taip padaryta daugiau deklaruojant protestą prieš politinių oponentų siūlymus. Tai ypač pasakytina apie M. Sleževičių, kuris, kaip minėta, pačiame RLSP paragino kitus Seimo atstovus pasisakyti už nepriklausomą Lietuvą. Galbūt todèl apie M. Sleževičiaus poziciją RLSP palankiai atsiliepė ir A. Smetonos biografas bei apologetas Aleksandras Merkelis: „Mykolas Sleževičius visa savo jautria širdimi ir revoliucinio svaigulio nepaveiktu protu norejjo balsuoti už nepriklausomybès reikalavimą, bet partinė drausmė vertė daryti priešingai“"63. M. Sleževičius apibūdintas kaip ,aštraus proto žmogus, demokratas visa siela, svetimas betkuriai

${ }^{61}$ Skipitis, R. Nepriklausoma Lietuva. Chicago, 1967, p. 27-28.

${ }^{62}$ Skipitis, R. Nepriklausoma Lietuva. Chicago, 1967, p. 28-29.

${ }^{63}$ Merkelis, A. Antanas Smetona: jo visuomeninè, kultūrinè ir politinè veikla. Vilnius, 2017, p. 188. 
Willezur Macht (prieš jègos valios naudojimą - M. T.)“64. Kitais duomenimis, M. Sleževičius „labai sujaudintas ir dideliu balsu pranešè, kad, visa savo širdimi ir visu protu esąs už Nepriklausomą Lietuvą, tik deja, pats partijos disciplinos verčiamas už Nepriklausomybès šūkị balsuoti negalịs, o balsuosiąs prieš ${ }^{\text {“c65 }}$. K. Griniaus teigimu: 1) Petrogrado seime M. Sleževičius, prieš savo frakcijos nusistatymą, savo vardu kalbėjo ir reikalavo Lietuvos nepriklausomybės. 2) M. Sleževičius buvo nusistatęs prieš išẻjimą iš bendrojo seimo ir pačiame išẻjime nedalyvavo nei su vèliava, nei be vèliavos"66. Kaip liudija kiti šaltiniai, M. Sleževičius vis tik su kitais kairiaisiais po dešiniųjų rezoliucijos prièmimo iš seimo posèdžio pasitraukè.

Dėmesio vertas ir R. Skipičio pastebejjimas, jog ,išèjusiųjų rezoliucijos tekstą, galima sakyti, paruošè nuosaikieji, todèl ir šiandien negalima sakyti, kad jis buvo blogas ar kenksmingas Lietuvos reikalui. Tik priešingų grupių agitacija sugebèjo taip iškraipyti tiesą, kad net prezidentas Smetona, kalbėdamas ị savąji (IV) seimą [1936 m.], (...) sakè, jog Petrapilio seime mūsų kairieji ir santariečiai nereikalavo Lietuvai nepriklausomybės, o tik autonomijos ${ }^{\text {"6 } 67}$. Beje, M. Sleževičius vertino panašiai abi RLSP priimtas rezoliucijas ir esminių skirtumų nemate், nes „ir vienų ir kitų rezoliucijoj yra vienas bendras taškas (reikalavimas): „Steigiamojo Lietuvos Seimo, kurs nustatytų Lietuvos valdymo formą ir Lietuvos santykius su kaimyninėmis tautomis“. Esą visa kita - „tai menkniekis“68. Tuo tvirtai buvo įsitikinęs M. Sleževičius, karštai gynęs Lietuvos nepriklausomybès atkūrimo idèją.

${ }^{64}$ Mitrulevičius, G. Lietuvos socialdemokratijos ideologinè-politine raida 1914-1919 metais. Vilnius, 2017, p. 457, žr. ten esančią 366 išnašą.

${ }_{65}$ Merkelis, A. Antanas Smetona: jo visuomeninè, kultūrinè ir politinè veikla. Vilnius, 2017, p. 189.

${ }^{66}$ Dr. K. Grinius. P. L. Vaitekūnas ,jestzlepoinformowany“. Lietuvos žinios. 1922, lapkričio 25 , p. 4.

${ }^{67}$ Skipitis, R. Nepriklausoma Lietuva. Chicago, 1967, p. 28-29.

${ }^{68}$ Sleževičius, M. Dèl L.S.-L.P. programos ir taktikos. Naujoji Lietuva. 1917, rugsèjo 14 , p. 2. 


\section{Skilimas Lietuvos socialistų liaudininkų partijoje ir M. Sleževičiaus pozicija}

Kaip minèta, jau RLSP kardinaliai išsiskyrè LSLP narių M. Sleževičiaus ir M. Januškevičiaus pozicijos dèl Lietuvos ateities. Kaip netrukus paaiškejjo, šioje partijoje èmé gilèti takoskyra tarp vadovybès su P. Baliu, M. Januškevičiumi, V. Bielskiu priešakyje bei M. Sleževičiaus ir jo šalininkų. Konfliktas tapo akivaizdus, kai 1917 m. rugpjūti-rugsèji „Naujosios Lietuvos“ redakcija tikslingai LSLP nariams leido padiskutuoti aktualiais partiniais klausimais prieš rugsejjo viduryje suplanuotą šios partijos konferenciją.

I diskusiją įsitraukęs M. Sleževičius atskirame straipsnyje pažèrè daug kritikos LSLP programai ir taktikai69. Jis „be galo klaidingu žingsniu“ laikè gegužès $1 \mathrm{~d}$. socialistų liaudininkų konferencijos priimtą nutarimą dẻl žemès klausimo. M. Sleževičius nepritarè, kad visa žemè būtų konfiskuojama be užmokesčio ir klausė, kodèl konfiskuojama žemè, o nekonfiskuojami kapitalai. Kodèl kenčia tas, kuris užvakar dar dejjo kapitalą i žemę, o visai nenukenčia tas, kuris mieste namus ar fabriką nusipirko. Esą tai didelè neteisybė. M. Sleževičius taip pat siūlè Lietuvos nepriklausomybės klausimą programoje iškelti pirmoje vietoje šalia socializmo. Kadangi „laisvė tai ir tautos pilna laisvè - tai yra be galo didelis brangumas pats savaime“, todèl, M. Sleževičiaus nuomone, dèl nepriklausomybès kairieji socialistai būtinai ir pirmiausia turi kovoti. „Tik nepriklausomoje valstybeje tos valstybès liaudis yra vyriausias savo reikalų tvarkytojas. Taigi, mes būtinai turime reikalauti Lietuvai pilnos nepriklausomybès“. M. Sleževičius buvo ịsitikinęs, kad Lietuvos nepriklausomybès šūkį būtina „paleisti ì plačiąsias minias, nes tai vienintelis mūsų ginklas, vienintelẻ mūsų galybe்“. Jis pirmiausia tam siūlè paruošti liaudị, nes iškilus galimam ginčui dèl Lietuvos tarp Vokietijos ir kitų valstybių, Lietuvos gyven-

${ }^{69}$ Sleževičius, M. Dèl L.S.-L.P. programos ir taktikos. Naujoji Lietuva,. 1917, rugsejjo 14, p. 2-3. 
tojų pareikšta valia, visiškos nepriklausomybès reikalavimas „gali padèti mūsų likimą vienon ar kiton pusèn nukreipti“.

M. Sleževičius taip pat aštriai pasisakè ir dèl grupès, susispietusios apie „Naująją Lietuvą“, taktikos. Ją pavadino „griežtai netinkama“ ir nurodè jos esmę: „tos grupés taktika - kova ir kritika ne mūsų priešų idejjų ir programų, bet kai kurių asmenų“. M. Sleževičius siūlè kiek įmanoma vengti tai daryti ir dėmesi nukreipti ị ten, kur reikia, ir politinių priešininkų atveju nenaudoti jẻgos, išlikti švariems, demokratams. O dèl bendro tikslo - laisvos Lietuvos - jungtis kovoti su kitomis Lietuvos partijomis, kartu „p i l n ą $l$ a i s v ę L i e t u v a i s a vo žodís avo politikos reikalais tarti“. Tam tikslui pasiekti ragino atkurti iširusią LTT, veikusią prieš Rusijos lietuvių seimą Petrograde.

Viešai M. Sleževičiaus kritika neliko nepastebèta. To rezultatas jo kartu su F. Bortkevičiene, B. Matulioniu, F. Kaupu ir A. Rimka pašalinimas iš partijos. Tai įvyko rugsejjo $14 \mathrm{~d}$. LSLP konferencijos metu. Kaip nurodyta „Naujojoje Lietuvoje“, pašalintieji atsisakè vykdyti partijos nutarimus, reikalauja, kad „artimiausiu tikslu Partija pastatytų Lietuvos neprigulmybės reikalavimą, kad politikos, šelpimo ir kultūros darbui Partija dètųsi su klerikalinėmis ir buržuazinèmis partijomis, atsikartodami protestuoja prieš užimtą Partijos internacionalinę poziciją, sumini „neatsakantį“ žemès reikalų rišimą “70. LSLP vadovybè toliau laikèsi ankstesnių nuostatų, savaip aiškino Lietuvos nepriklausomybės klausimą: „Teisė laisvai apsispręsti demokratingai išrinktame suvereniame Lietuvos Steigiamajame susirinkime kame mūsų šalies darbo demokratija stovès už respublikinę tvarką ir federatų susijungimą su viena ar keliomis (tai geriausia bus matyti vietoje) demokratinemis šalimis - štai tiksliausias šiuo metu reikalavimas" ${ }^{\text {"71 }}$. Kaip matyti, Lietuva neturèjo būti visiškai nepriklausoma, o sudaryti federaciją su viena ar keliomis demokratinèmis valstybèmis. Minėtoje

70 Jūraitis, M. Kodèl tas atsitiko? Naujoji Lietuva, 1917, gruodžio 3, p. 1.

${ }^{71}$ Ten pat. 
partijos konferencijoje ị naują LSLP centro komiteto prezidiumą buvo išrinkti: M. Januškevičius - pirmininkas, A. Bulota ir P. Balys - pirmininko padejejjai, V. Bielskis - kandidatas ${ }^{72}$.

M. Sleževičiaus reakcija i aprašytus ịvykius paaiškejja iš jo laiško, adresuoto LSLP (Vitebske) pirmininkui Jonui Grigaičiui. Laiškas parašytas praejjus vos trims dienoms nuo antrosios LSLP konferencijos. Kaip matyti iš M. Sleževičiaus teksto, tarp LSLP narių dèl programinių nuostatų ir taktikos nesutarimų būta ir po pirmosios partijos konferencijos. Esą jie išryškejjo antrosios konferencijos metu, „kuomet Lietuvos politinę ateitị galutinai jau surišame su Rusijos Demokratijos likimu ir kuomet konferencija nutaria susirišti federacijos ryšiais su rusų soc.-revol. partija (prytam dar su tos partijos kairiuoju sparnu - internacionalistais ar maksimalistais) ir kuomet rezoliucijoj papeikiama dr. Bielskio žygiai Kijevo suvažiavime, kame buvo nutarta reikalauti iš Rusų vyriausybès paskelbimo akto apie Lietuvos suverenę valstybinę teisę“. Kaip toliau sakoma laiške, „Centro Komitete dauguma visgi Balio šalininkai, ir vargu jie beleis rezoliucijas ištaisyti taip, kaip to norètų Bielskis ir Sugintas, kurie vis dar tikisi atversti Bali i teisingą kelią. Jie vis dar tikisi, net ir tuomet, kada visi Petrogrado darbininkai ir visos vidurinių moksleivių kuopos grynai bolševikiškos dvasios persisunkę ir klauso Balio kaip pono Dievo“. Toliau M. Sleževičius pozicijų skirtumus LSLP tarp atsiradusių dviejų stovyklų aiškino su partijos antrosios konferencijos priimtais sprendimais. Štai keletas esminių skirtumų: konferencija atmetė M. Sleževičiaus ir jo šalininkų pasiūlymą tuoj iškelti Lietuvos nepriklausomybės „idèjos obalsị “ ir visomis jègomis dèl tos nepriklausomybès tuoj pat kovoti; atmeté pasiūlymą „tuoj sudaryti Vyriausị Tautos Organą“ (i jị turejo ịeiti ir kitų lietuvių partijų atstovai - M. T.); konferencija nukrypo ì „bolševizmo vagą“, atsistojo „ant III internacionalo pamato“. Galiausiai, kaip nurodè M. Sleževičius, kai konferencija „atmetė by

${ }^{72}$ Iš L. S. L. Partijos gyvenimo. Naujoji Lietuva, 1917, lapkričio 11, p. 1-2. 
kokị kontaktą su visų tautų, taigi ir savo tautos bei šalies, nesocialistinemis partijomis; kada lygiai, kaip ir rusai bolševikai atsistojo ant pamato vien socialistinès rusų vyriausybès, - tai mums ir galutinai paaiškejjo, kad tolimesnis mūsų tylèjimas būtų prasižengimas prieš tautą ir visą šalị, taipgi, žinoma, ir prieš partijos ateitị, ir todèl nutarẻme paskelbti savo deklaraciją einamuoju momentu ir toliau veikti jau pilnai savarankiai, stovedami ant 1914 m. L. Socialistų Liaudininkų Demokratų Partijos patvirtintos programos bei taktikos pamatų“. Esą tai buvome priversti padaryti dar ir „labiausia todèl, kad Lietuvos likimas, jei dabar tinkamai nebus išrištas, tai gal ir niekuomet jie nebus išrištas“; „taigi turime reikalauti kad Lietuva būtų paskelbta visai nepriklausoma"73. Akivaizdu, kad M. Sleževičiaus ir jo šalininkų požiūris ị svarbius klausimus gerokai skyrèsi nuo oponentų LSLP.

Todèl, kaip laiške M. Sleževičius pripažino, tuo metu susidarė du partijos sparnai su atskirais CK: 1) Lietuvos socialistų liaudininkų demokratų partija, kuri laikosi 1914 m. partijos suvažiavimo nustatytos programos bei taktikos; 2) internacionalistai - Lietuvos socialistųliaudininkų partija. Pasak M. Sleževičiaus, „mūsų tautos ir visos šalies likimas ant bedugnès kranto kabo“, „nemaža mūsų ateitis prigulès ir nuo mūsų pačių elgimos“. Todèl M. Sleževičius kvietė Vitebske veikusius LSLP narius prisidèti prie jo CK vedamos politinès linijos ${ }^{74}$.

Tuo tarpu J. Grigaitis M. Sleževičiaus idejoms nepritarė ir pasisakè prieš partijos skilimą, nes laikèsi teigiamos nuomonès apie internacionalą („mes manome, kad lietuviai kaip tik turi būti internacionalistais“) bei abejojo vienų lietuvių pastangomis iškovoti Lietuvai nepriklausomybę („lietuviai vieni sau eidami laisvès sau neiškovos" $)^{75}$.

${ }^{73}$ M. Sleževičiaus 1917 m. rugs. 27 d. laiškas Lietuvos socialistų Liaudininkų partijai Vitebske. LMAVB RS, f. 199-2, 1. 63-71.

74 M. Sleževičiaus 1917 m. rugs. 27 d. laiškas Lietuvos socialistų Liaudininkų partijai Vitebske. LMAVB RS, f. 1992, 1. 63-71.

75 J. Grigaičio laiškas M. Sleževičiui ị Jaroslavlį. Atsakymas ị jo laišką, 1917 spal.18. LMAVB RS, f. 199-2, 1. 72. 
Kadangi tokių kaip J. Grigaitis buvo nemažai, 1917 m. rudenị dèl M. Sleževičiaus laiške išvardytų principinių pozicijų skirtumų, atsiradus dviem priešingiems LSLP sparnams, partija skilo. „Kada 1917 m. partijos kairioji dalis, rusų kairiųjų eserų ịtakoje būdama, atsistojo ant kelio, kuris veste vertė bendradarbiauti su komunistais - bolševikais, o dešinioji jos dalis: p. F. Bortkevičienè, D-ras Matulionis, Kaupas, A. Rimka ir M. Sleževičius - pasiskelbẻ esanti tikroji Varpininkų-Demokratų idèjų nešẻja ir, pasivadinusi Lietuvos Socialistų Liaudininkų Demokratų Partija, šaukè visus varpininkus - demokratus - liaudininkus susispiesti apie juos ir neleisti partijai žūti, vieni pirmųjų atsiliepė D-ras K. Grinius ir Dr. J. Staugaitis. Jų aiški pozicija, jų vardai sustiprino ir vèl suspietė didelius būrius partijos žmonių apie varpininkų - demokratų - liaudininkų tradicinę vèliavą"76, - po kelerių metų taip šiuos įvykius aiškino pats M. Sleževičius. Iš tiesų tarp LSLP ir LSLDP išliko principiniai skirtumai, dèl kurių abi partijos nevengè viena kitai aštrios kritikos ${ }^{77}$. Beje, „Naujoji Lietuva“ toliau atstovavo LSLP su P. Baliu priešakyje. I šią partiją ìstojo daug naujų ir jaunų žmonių, „su partijos ideologija nẻ tradicijomis visai nesusirišusių “78. LSLP 1917 m. pabaigoje Maskvoje surengè dar vieną konferenciją, dar kiek vèliau Rusijos gilumoje žuvus P. Baliui, jos nariai išsiskirstè $\dot{~}^{79}$.

Idomumo dèlei reikia pasakyti, jog po partijos skilimo ị leidinio „Naujoji Lietuva“ redakciją ìejo ir A. Sugintas, nepriklausomoje Lietuvoje ịsijungsiantis i $\mathrm{M}$. Sleževičiaus vadovaujamos partijos gretas. Iš to galima spręsti, kad ir po partijos skilimo buvo galimybė pereiti iš vienos partijos ị kitą. Pažymètina, kad Rusijoje valdžioje įsigalejus bolševikams ir ịvedus totalitarinị valdymą, kitos partijos, išskyrus

76 Sleževičius, M. D-as Kazys Grinius politikoje (atsiminimų žiupsnelis). Varpas. Dr. K. Griniaus 60 m. jubiliejui skirtas numeris. 1926, p. 199.

77 Jūraitis, M. Neapsirikite! Naujoji Lietuva. 1917, gruodžio 10, p. 1-2.

78 R. [Ruseckas P.]. Trumpa Lietuvos socialistu liaudininkų demokr. partijos istorija. Kaunas, 1919, p. 8.

79 Sugintas, A. Tarp dviejų revoliucijų 1905-1917 m. Iš Valstiečių liaudininkų sąungos praeities. Sëja. 1958 m., Nr. 3, p. 9. 
bolševikų, buvo uždraustos arba ėmè išpažinti iš esmès bolševikams artimas idejjas. Tai pasakytina apie LSLP, kuri $1918 \mathrm{~m}$. rudeni èmè vadintis Lietuvos revoliucionierių socialistų liaudininkų partija. Dèl Rusiją sukrètusių politinių ìvykių partija išgyveno krizę: dalis jos narių nuejo pas bolševikus ar išpažino jų idejjas, dalis nuo bolševikų valdžios nukentejjo, dar kiti buvo priversti bėgti iš Sovietų Rusijos. Buvo ir tokių, kurie, kaip M. Januškevičius, minėtas A. Sugintas (šis 1918 m. pabaigoje, kaip besilaikąs ne savo partijos „programinių nuostatų“, nes sutiko būti kooptuojamas dirbti teisininkų komisijoje prie Lietuvos Tarybos Vilniuje, iš LSLP buvo pašalintas ${ }^{80}$ ), J. Krikščiūnas, V. Bielskis, Bakanauskas, prieš tai, kaip nesutikdami su savo partijos linija, buvo iš jos pašalinti ${ }^{81}$, atsidūrè nepriklausomoje Lietuvoje. Taigi neišsipildè ir jų siekis matyti Lietuvą federacijoje pirmiausia su demokratine Rusija (beje, ir šios Laikinoji vyriausybè „nepadarè nė vieno žingsnio pirmyn, kad patenkinus lietuvių reikalavimus“ dèl Lietuvos nepriklausomybės ${ }^{82}$ ) ar kita demokratine valstybe. Pagaliau nebuvo igyvendintas ir $1918 \mathrm{~m}$. rudeni LSLP IV konferencijos priimtas nutarimas „Reikalauti „Lietuvos darbo žmonių tarybų respublikos“83.

Atsižvelgus ì tai, nereikia stebètis, kad su radikaliuoju sparnu nuèję lietuvių politikai, nesugebèję îsijungti ị M. Sleževičiaus ar kitas demokratines vertybes išpažinusias politines partijas, vèliau nesèkmingai bandè dalyvauti nepriklausomos Lietuvos politiniame gyvenime. Kaip antai M. Januškevičiaus ir jo šalininkų mėginimas 1922 m. spalị su savo sąrašu „Žemès ir laisvès“ dalyvauti rinkimuose

${ }^{80}$ C. K. nutarimai dèl kurių-nekurių buvusių P. narių. Naujoji Lietuva. 1918, lapkričio 15 , p. 16.

${ }^{81}$ Lietuvos revoliucinių socialistų-liaudininkų partijos centro komitetui. Naujoji Lietuva. 1918, lapkričio 15, p. 16-17.

82 Lietuvių deklaracija valstybės pasitarime Maskvoje. M. Januškevičiaus padarytas pranešimas nuo lietuvių. Naujoji Lietuva. 1917, rugpjūčio 31, p. 1.

${ }^{83}$ Lietuvos revoliucinių socialistų-liaudininkų partijos centro komitetui. Naujoji Lietuva. 1918, lapkričio 15, p. 16-17. 
i I Seimą ${ }^{84}$. Ta proga M. Januškevičius net atgaivino laikraštị „Naujoji Lietuva“. Visos pastangos baigèsi nesèkme: nė vienas minėto sąrašo atstovas nepateko ị Seimą, o po pirmo išleisto numerio daugiau dienos šviesos neišvydo ir „Naujoji Lietuva“. Lietuvos rinkejjams ši radikali politinè jèga buvo svetima ir jos atstovai su lyderiu M. Januškevičiumi taip ir liko politinès arenos užribyje. Tuo tarpu A. Sugintas, J. Krikščiūnas atliko svarbų vaidmenị M. Sleževičiaus vadovaujamoje partijoje. Taigi socialistų liaudininkų skilimą galima vertinti prieštaringai: viena vertus, vertinant narių kiekybę, jis partiją susilpnino, kartu ir kompromitavo lietuvių akyse dèl nevieningo požiūrio ị Lietuvos nepriklausomybę. Antra vertus, jis socialistus liaudininkus apvalè nuo nepriimtinų $\mathfrak{x}$ bolševizmą linkusią narių. Kartu skilimas išgelbejjo partiją nuo galutinio sunykimo. Tai jai išejo ì naudą. Taigi $1917 \mathrm{~m}$. pabaigoje M. Sleževičiaus pasirinkta taktika pasiteisino ir dèsninga, kad jo vadovaujami socialistai liaudininkai demokratai, po Pirmojo pasaulinio karo sugrịžę ị tėvynę, aktyviai įsijungè ị politinị gyvenimą. Čia Lietuvos nepriklausomybès šalininkai po partijos skilimo, priešingai nei radikalioji LSLP, èmé bendradarbiauti su kitomis lietuvių partijomis. Tai daryta dar 1917 m. pabaigoje, kai Lietuvių „Liaudies“ ir Lietuvių karininkų sąjungos, krikščionių-demokratų, Pažangos, Santaros, socialistų liaudininkų demokratų partijos, iniciatyvą parodžius Kaziui Griniui, Pranui Mašiotui ir Jonui Jablonskiui, Voroneže i̊steigè Vyriausiąją lietuvių tarybą Rusijoje.

\section{Vyriausiojoje lietuvių taryboje Rusijoje}

Rusijoje veikusi LTT baigė veiklą kartu su RLSP iširimu. Jame, išskyrus balsų dauguma priimtą rezoliuciją dẻl lietuvių tautos apsisprendimo siekti Lietuvos nepriklausomybès, nebuvo sudaryta jokia valdžios institucija, kuri rūpintųsi tai igyvendinti. Nors pradžioje

${ }^{84}$ Draugai Darbininkai ir Darbo Valstiečiai, visi balsuokit už Darbo žmonių „Žemès ir Laisvès"sąrašus! Naujoji Lietuva. 1922, spalio 1, p. 1. 
manyta kitaip ${ }^{85}$. Suvokus, jog ilgai taip negali būti, RLSP lietuvių politikai vèl ėmè kalbèti apie vienos visų lietuvių institucijos, kuri koordinuotų visų tautiečių veiklą Rusijoje, reikalingumą ${ }^{86}$.

Rusijos lietuviams čia susitarti nepavyko, tad juos pralenkè Lietuvoje veikę politikai. Jie pasiekè, kad 1917 m. rugsèji Vilniuje būtų sušaukta lietuvių konferencija, kurios nariai pasisakẻ už demokratinę nepriklausomą Lietuvą. Šiam tikslui igyvendinti slaptu balsavimu buvo išrinkta 20 asmenų Lietuvos Taryba (LT), o jos pirmininku A. Smetona. LT pasitikejjo viso krašto gyventojai, jos siekius rèmè išeivijos lietuviai. Taigi Vilniaus konferencija išreiškè iš atskirų partijų programų perkeltą viso krašto gyventojų siekimą sukurti nepriklausomą Lietuvą.

1917 m. rudenị subruzdo ir Rusijoje veikę lietuviai. Karininkų sąjungos iniciatyva lapkričio $16 \mathrm{~d}$. ị Voronežą suvažiavę lietuvių partijų atstovai po keturių dienų posėdžiavimo išrinko naują tarybą, kuri pasivadino Vyriausiąja lietuvių taryba Rusijoje (VLTR). Ją sudarė dauguma lietuvių partijų. Kaip nurodyta spaudoje, tarp jų nebuvo tik „iš pačių kairiųjų partijų, kurios negali atitraukti nuo paleisto prieš jų akis rusų demokratijos miražo" ${ }^{\text {"87 }}$.

Minètame renginyje Voroneže, kuriame iš LSLDP dalyvavo M. Sleževičius ir Albinas Rimka, pasisakyta už Lietuvos nepriklausomybès atkūrimą etnografinèse ribose ${ }^{88}$. Būsimos Lietuvos valdymo formą ir vidaus tvarką, taip pat santykius su kaimyninėmis ir kitomis valstybėmis turèjo nustatyti Steigiamasis Seimas Vilniuje, išrinktas visuotiniu („be lyties, tikybos ir tautos skirtumo“), lygiu, tiesiu ir slaptu balsavimu proporcine sistema ${ }^{89}$. I LVTR ịejo Kazys Grinius, Jonas

${ }^{85}$ Rgn. Lietuvių Tautos Taryba. Lietuvių balsas. 1917, liepos 16, p. 1; liepos 20, p. 1. ${ }^{86}$ Rgn. Derybos dèl Lietuvių Tautos Tarybos. Lietuvių balsas. 1917, liepos 23, p. 1.

${ }^{87}$ Nauja Tautos Taryba. Lietuvių balsas. 1917, lapkričio 24, p. 1.

${ }^{88}$ Trijų ir Partijų atstovų suvažiavimas Voroneže. Lietuvių balsas. 1917, lapkričio 24, p. 2.

89 Trijų ir partijų atstovų suvažiavimas Voroneže. Lietuvių balsas. 1917, lapkričio 30, p. 2. 
Jablonskis ir Pranas Mašiotas - nerinkti, Lietuvių karininkų sąjungos Centro komiteto igalioti sudaryti „Vyriausiają Lietuvių Organą“. Kiti asmenys buvo išrinkti vienbalsiai: kun. Julijonas Jesenskis, M. Yčas, Jonas Kriščiūnas, kun. Pranas Penkauskas, Vytautas Petrulis, Liudas Noreika, M. Sleževičius, S. Šilingas, kun. Juozas Vailokaitis, dr. Juozas Bagdonas, kun. Emilijonas Paukšta ir R. Skipitis ${ }^{90}$. M. Sleževičius buvo LVTR vicepirmininkas (kito vicepirmininko pareigas užèmé M. Yčas ${ }^{91}$ ), o nuo 1918 m. sausio - jos pirmininkas. Čia jis pakeitè bendramintị K. Grinių, dèl sudètingų sąlygų negalèjusị būti Voroneže (ten buvo įsikūręs tarybos prezidiumas). K. Grinius pasiliko Kaukaze, todèl ir nuo pradžios faktinis pirmininkas buvo M. Sleževičius ${ }^{92}$.

Pradejjusi veikti LVTR buvo lietuvių, gyvenusių Rusijoje, aukščiausia valdžios institucija, ir pagal svarbą ją galima lyginti su Vilniaus lietuvių konferencijoje išrinkta ir Vilniuje veikusia LT. Skirtumas tik tas, jog viena valdžios institucija veikè Rusijoje, o kita vis dar Vokietijos okupuotoje Lietuvoje. Svarbiausia - abiem lietuvių valdžios institucijoms nebuvo galima laisvai veikti, o Rusijoje įsigalejjus valdžioje bolševikams, kategoriškai nusistačiusiems prieš Lietuvos nepriklausomybę $e^{93}$, LVTR veikla buvo komplikuota. LVTR nariams grèsė areštai. $1918 \mathrm{~m}$. vasario $21 \mathrm{~d}$. LVTR posėdžio protokole M. Sleževičius pranešè, kad Voroneže sklinda gandas, jog vietos komunistams duotas įsakymas areštuoti visą LVTR, „jei tiktai ji pradètų davinèti pasus“94. Gandai pasitvirtino ir netrukus M. Sleževičius drauge su kitais LVTR nariais, išskyrus P. Mašiotą, buvo suimti bolševikų Voroneže ir pasodinti ị kalèjimą. Kovo $9 \mathrm{~d}$. Voronežo kareivių, darbininkų ir vals-

90 Trijų ir partijų atstovų suvažiavimas Voroneže. Lietuvių balsas. 1917, lapkričio 30, p. 3.

91 Lietuvių Vyriausiosios Tarybos posėdžiai Voroneže 1917 m. gruodžio m. 1-5 d. Lietuvių balsas. 1917, gruodžio 7, p. 1.

92 Klimas, P. Dienoraštis. Chicago, 1988, p. 245.

93 Yčas, M. Lietuvos Reikalų Komisaras apie Lietuvos Nepriklausomybę (Pasikalbèjimas su V. Kapsuku Mickevičium). Lietuviu balsas. 1917, gruodžio 23, p. 2.

94 Angarietis, Z. Vokietijos koštuvas. Komunistas. 1918 m., Nr. 6, p. 40. 
tiečių tarybos leidžiamose "Izvestijose“ buvo nurodyti kaltinimai, už ką LVTR nariai buvo suimti: „1) už skelbimą Lietuvos nepriklausoma valstybe, 2) už siuntimą savo atstovo ị taikos derybas Lietuvos Brastoje, 3) už darymą grynai ekonominių ir politinių santykių su Ukrainos Rada, 4) už organizavimą lietuvių inteligentų ir liaudies grịžti ị Lietuvą, 5) už išdavinejjimą lietuvių asmens liudijimų ir 6) už visą L.V.T.R. kontrrevoliucinị veikimą"

LVTR nariai kalejo daugiau kaip mėnesį; ị laisvę paleisti vasario 27 d. ${ }^{96}$; M. Sleževičius kurị laiką kartu su Z. Žemaičiu buvo laikomas namų arešte ${ }^{97}$; kitais duomenis - LVTR nariai buvo areštuoti 1918 m. vasario pabaigoje, o kovo pabaigoje buvo išleisti iš kalejjimo ị laisvę ${ }^{98}$. Ištrūkę iš kalèjimo LVTR nariai išsiskirstè: vieni parvyko ị Lietuvą, kiti išvyko į Maskvą ar Petrogradą, treti liko Voroneže rūpintis lietuvių tremtinių sugrịžimu ị Lietuvą.

M. Sleževičius, paleistas iš kalejjimo, išvyko ị Maskvą, kur siekẻ iš Voronežo perkelti LVTR centrą i Maskvos lietuvių šelpimo draugijos būstinę. Tačiau apie tai informavus spaudą, jau kitą dieną bolševikų valdžia šioje būstinejje atliko kratą. Nors lietuvių spaudoje buvo pranešta, kad kratos metu bolševikams nepavyko surasti LVTR dokumentų ${ }^{99}$, iš tiesų jie, tik nežinia, ar narių suėmimo metu, ar kitu būdu atsidūrẻ bolševikų rankose. Tai paaiškẻja iš komunisto Zigmo Alekso Angariečio bolševikų leidinyje „Komunistas“ paskelbto straipsnių ciklo, kuriame pateiktos gausios LVTR posėdžių protokolų ištraukos. Turèdamas tikslą parodyti LVTR narių veiklą tik iš blogosios pusès, Z. Angarietis publikacijoje šalia negatyvių komentarų pateikè ir nemažai vertingų ištraukų iš minètos organizacijos posėdžių protoko-

95 Būtėna,s J., Mackevičius, M. Mykolas Sleževičius..., p. 68.

96 Yčas, M. Rusijos lietuvių pastangos kovose už Lietuvos nepriklausomybę. Pirmasis nepriklausomos Lietuvos dešimtmetis. Kaunas, 1990, p. 32.

97 Žinios. Vadas. 1918, balandžio 7, p. 2.

98 Čepènas, P. Naujausiujų laiku Lietuvos istorija. Vilnius, 1992, II tomas, p. 78.

99 Grigaravičiūtè, S. Lietuvos Tarybos atstovavimas Rusijoje 1918 metais. Parlamento studijos. 2017 m., Nr. 23, p. 26. 
lų bei informacijos iš LVTR narių korespondencijos bei kitų šaltinių. Neturint galimybès susipažinti su LVTR posėdžių protokolais, net ir iš komunistų spaudoje paskelbtos medžiagos ${ }^{100}$ galima susidaryti gana išsamų vaizdą apie minètos organizacijos veiklą. Komunistų paskelbti dokumentai liudija, kad trumpą laiką veikusi LVTR stengèsi aktyviai dirbti. Pirmiausia, LVTR siekė užmegzti glaudžius ryšius su ukrainiečiais, kad jų dèka pavyktų lietuvių atstovams dalyvauti Bresto taikos derybose tarp Vokietijos (ir jos sąjungininkų) ir Sovietų Rusijos atstovų. LVTR, nenorėdama kreiptis ị Sovietų Rusiją, bendraudama su ukrainiečiais, siekė apeiti V. Lenino vadovaujamus komunistus. Tuo tikslu M. Sleževičius 1917 m. pabaigoje turejjo važiuoti ị Kijevą, kad „prieitų prie ukrainiečių“. Planui pavykus, jis galejo ir „visai pasilikti Kijeve, kaipo nuolatinis lietuvių atstovas prie Ukrainos Rados“. Tai laikyta labai svarbiu ịvykiu. Kitame LVTR posėdžio protokole nurodyta, kad ị Bresto taikos derybas siunčiami dr. Alekna ir A. Voldemaras. Be to, nutarta siųsti delegatus ị Kijevą pas ukrainiečius, kad „jie Breste paremtų lietuvių atstovybės reikalą“. İ Kijevą be M. Sleževičiaus nutarta pasiųsti ir R. Skipitị. Tame pačiame posėdžio protokole nurodyta: „Iš Kijevo M. Sleževičius važiuoja ị Brastą. Igaliojimus jam įduoda Voronežo Taryba"101.

Tačiau iš gruodžio 25 d. S. Šilingo telegramos, adresuotos P. Mašiotui, paaiškejja, kad numatyta išsiųsti ị Brestą A. Voldemarą, Alekną ir M. Sleževičių, o nuolatinị atstovą Kijeve - Petrą Leoną. Iš sausio 15 d. R. Skipičio telegramos, adresuotos Jablonskienei, matyti, jog A. Voldemaras išvyko ị Brestą, o Alekna ir M. Sleževičius dar neatvyko ị Kijevą. Tuo metu Kijeve veikè Ukrainos parlamentas - Rada, kuri buvo nuginklavusi vietinę iš Sovietų Rusijos siųstą komunistų kariuomenę. Taigi tuo metu bolševikai lietuviams ir ukrainiečiams buvo bendras priešas. Lietuva ir Ukraina siekè būti nepriklausomomis

${ }^{100}$ Angarietis, Z. „Tèvynès gelbėtojų“ žygiai. Komunistas. 1918 m., Nr. 3, p. 14-16; Nr. 4, p. 24-25.

${ }^{101}$ Angarietis, Z. ,Tėvynès gelbėtojų“ žygiai. Komunistas. 1918 m., Nr. 3, p. 15. 
valstybėmis. LVTR Ukrainos Radą vertino kaip „laisvès idealą ir visų pavergtųjų tautų nepriklausomybės šviesiųjų idealų gaivintoją “102.

Iš bolševikų paviešintos informacijos apie LVTR paaiškèja, jog 1918 m. sausio 28 d. jos posėdyje svarstytas klausimas dèl lietuvių kariuomenès organizavimo. Ten pat nurodyta, kad iki šiol nieko realaus nenuveikta. Bet kartu pažymėta, jog „Voldemarui buvo pavesta tartis su vokiečiais, kad būtų leista sudaryti lietuvių kariuomenę iš belaisvių, kurių priskaityta apie 25000 žmonių “103. Pagal tai galima spręsti, kad LVTR siekè veikti su Ukrainos Rada ir Vokietija prieš Sovietų Rusiją, pirmiausiai siekiant apsisaugoti nuo bolševikų ekspansijos. Tuo tikslu ketinta pasinaudoti Ukrainos Rados pagalba ir net kurti savo kariuomenę. Tačiau šie sumanymai nebuvo realizuoti: Ukrainai nepavyko išlaikyti nepriklausomybės (1918 m. vasarị ją okupavo Sovietų Rusijos kariuomenè), kaip rašyta, LVTR vadovybės nariai buvo suimti. Todèl M. Sleževičiui nepavyko išvykti į Kijevą, nekalbant apie dalyvavimą Bresto taikos derybose.

Iš paskelbtų dokumentų matyti, kad $1918 \mathrm{~m}$. sausio antroje pusejje M. Sleževičius pasisakè už lietuvių kariuomenès organizavimą ir profesinių sąjungų mobilizavimą. Tuo tarpu LVTR narys Z. Žemaitis siūle parengti atsišaukimą, kuriame nurodyti, jog Vokietijos kariuomenè negalinti pasitraukti iš Lietuvos, nes Lietuva neturi nei pašto, nei telegrafo, nei geležinkelių, nei tų bei kitų valstybinių i̇staigų tarnautojų ${ }^{104}$. Taigi savo karinèmis pajėgomis kartu su Vokietijos kariniais daliniais M. Sleževičius ir LVTR ketino kovoti prieš galimą Sovietų Rusijos kariuomenès įsiveržimą ị Lietuvos teritoriją. Be to, kaip minèta, LVTR dar mėgino gelbèti lietuvius tremtinius jiems išduodama lietuviškus pasus (vèliau saugumo sumetimais jie pavadinti paliudymais) ${ }^{105}$.

${ }^{102}$ Angarietis, Z. ,Tèvynès gelbėtojų“ žygiai. Komunistas. 1918 m., Nr. 4, p. 25.

${ }^{103}$ Angarietis, Z. Nuimkite maskas. Komunistas. 1918 m. Nr. 4, p. 22.

${ }^{104}$ Angarietis, Z. , ,Tèvynès gelbėtojų“ žygiai. Komunistas. 1918 m., Nr. 4, p. 25.

${ }^{105}$ Angarietis, Z. Vokietijos koštuvas. Komunistas. 1918 m., Nr. 5, p. 32-34. 
Kaip toliau paaiškejo, M. Sleževičius ir išejęs ị laisvę, Rusijoje viešpataujant bolševikų valdžiai, pagal galimybes bandè rūpintis lietuvių reikalais. Jis kartu su Maskvos lietuvių šelpimo draugijos pirmininku Konstantinu Lapinu palaikė ryšius su Vokietijos generaliniu konsulu Maskvoje (1918 m. liepą - rugpjūtị). Šis bendradarbiavimas pasitarnavo, kad Lietuvos piliečiams Maskvoje būdavo išduodami paliudijimai, „kurių pagrindu Vokietijos generalinis konsulas išduodavo jiems Lietuvos piliečio pasą ir apsaugos raštą"106. Šių dokumentų gavimas lietuvių pabėgėliams palengvino sąlygas parvykti į Lietuvą.

\section{Lietuvos nepriklausomybès netolimos ateities perspektyvos}

Gyvendamas Voroneže, atrodo, 1918 m. pradžioje, taigi LT Vilniuje dar prieš priimant vasario $16 \mathrm{~d}$. Lietuvos nepriklausomybès aktą, M. Sleževičius parašė ir išleido brošiūrą „Ko nori Lietuvos SocialistųLiaudininkų Demokratų Partija“, o žurnale „Varpas“ paskelbė didelès apimties straipsnị „Lietuvos nepriklausomybe்“. Minètuose leidiniuose autorius išdėstė požiūrị i Lietuvos nepriklausomybès perspektyvas bei būsimą valstybès santvarką.

Kaip nurodoma leidinyje „Ko nori Lietuvos Socialistų-Liaudininkų Demokratų Partija“, „vyriausias Lietuvos Socialistų-Liaudininkų Demokratų idealas: politikoje - laisva, niekam nepriklausoma Lietuvos demokratinè respublika, kuri su kitomis tautomis lygiomis teisėmis sudaro viso pasaulio Tautų Federaciją “107. M. Sleževičiaus supratimu, „Lietuvos nepriklausomybè - dienos klausimas“. Šj teiginị jis argumentavo tokiais faktais: Rusijoje gyvenančių lietuvių Seimas

${ }^{106}$ Grigaravičiūtè, S. Lietuvos Tarybos atstovavimas Sovietų Rusijoje 1918 metais. Parlamento studijos. 2017 m., Nr. 23, p. 40-42.

${ }^{107}$ Sleževičius, M. Ko nori Lietuvos Socialistų-Liaudininkų Demokratų Partija. Voronežas, 1918 m., p. 12. 
Petrograde 1917 m. gegužès 27 d. prièmé nutarimą reikalauti Lietuvai nepriklausomybès; $1917 \mathrm{~m}$. Vilniuje lietuvių politikai bei $1915 \mathrm{~m}$. JAV lietuviai iškèlė Lietuvos nepriklausomybès reikalavimą; Rusijos tautų suvažiavimas Kijeve nutarè priminti Laikinajai Rusijos vyriausybei, jog ši paskelbtų dekretą apie Lietuvos nepriklausomybę; „Rusijos revoliucinė Demokratija, nakaze (ísakyme - M. T.) savo atstovui Skobelevui, kuris siunčiamas ị Paryžiaus Konferenciją, irgi leidžia jam reikalauti, kad Lietuvai būtų pripažinta teisè savo Steigiamajame Seime savo politinę ateitị nulemti“. M. Sleževičiaus supratimu, „tokie momentai, kaip šis, pasikartoja retai - sykị per kelis šimtus ir net tūkstančius metų. Nuo to, kaip mes dabar pasielgsime, ką tesėsime iškovoti, prigulès tolesnè mūsų ateitis“. Jis buvo ịsitikinęs, jog sprendžiant Lietuvos ateities klausimą, „labai ir labai daug, daugiau negu kad mes patys manome, prigulès nuo mūsų pačių, kaip galutinai bus Lietuvos politinės ateities klausimas išrištas" ${ }^{108}$. Kaip matyti, M. Sleževičius, užuot viską palikęs spręsti kitoms valstybėms, daug tikẻjosi iš pačios lietuvių tautos. Savo tauta šis politikas tikès ir nepriklausomybės laikotarpiu. Tuo jis skirskis nuo kai kurių politikų, kaip antai A. Smetonos, kuris ypač autoritarizmo metais tautai primes savo valią iš viršaus. Tokiomis sąlygomis tautai beliks tik vykdyti valdžios nurodymus.

İdomu, jog dar prieš atkuriant nepriklausomybę 1918 m. pradžioje M. Sleževičius Lietuvai prognozavo kelis variantus: „1) Europos ar net ir viso pasaulio tautų ar valstybių federacija, kurion šale kitų lygiomis teisemis ieina ir laisva nepriklausoma Lietuva; 2) Niekam nepriklausoma Lietuva šale kitų irgi niekam nepriklausomų tautų ar valstybių, kaip Danija, Švedija, Norvegija; 3) Lietuva, kad ir vidaus reikalais mažiau ar daugiau yra savaranki, bet kuriai nors kitai valstybei priklausoma“. M. Sleževičiaus nuomone, „kito išejjimo nèra ir negali būti. Jei pasiliktų taip, kaip iki šiolei buvo, vis tiek ar mes bū-

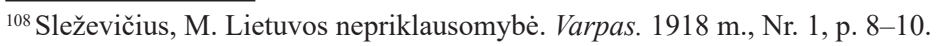


tume prie Rusijos palikti ar prie Vokietijos prijungti, - tai pasiliktų politinè Lietuvos vergija“. M. Sleževičiaus supratimu, „viso pasaulio ar bent Europos tautų - valstybių federacija tai dar tolimas idealas, prie kurio turi visos tautos ir valstybès eiti, prie kurio siekiame ir mes lietuviai“. Tokia federacija turèjo būti sukurta demokratiniu būdu, o „ne svetimos tautos ar valstybės prievarta“. Iš tolesnio M. Sleževičiaus aiškinimo akivaizdu, kad tokia Europos valstybių federacija galètų būti dabartinė Europos Sąjunga, ị kurią valstybès ịstojo savo noru, o kartu išsaugojo savo nepriklausomybę. Tačiau toks valstybių darinys, pasak M. Sleževičiaus, galèjo susikurti tik tolimoje ateityje, „kada visų tautų reikalas spirs jas tokią federaciją sudaryti"109. Kaip matyti, Lietuva ị tokị valstybių derinị įsijungè tik 2004 m., t. y. praejjus daugiau nei šimtui metų, prieš tai pergyvenusi sudètingas sovietų ir nacių okupacijas.

M. Sleževičius Lietuvos nepriklausomybès klausimo sprendimą siejo su Pirmojo pasaulinio karo pabaiga, nes: „1) Lietuvos ateities klausimas bus rišamas tarptautiniame taikos kongrese; 2) Lietuvos klausimas jau ne Rusijos ir ne Vokietijos vidaus klausimas - jis jau tarptautinis klausimas; 3) dèlei susidariusių politikos aplinkybių Rusijos ir Vokietijos dèl Lietuvos varžytinių - šis momentas tinkamiausias Lietuvos nepriklausomybès reikalavimui pastatyti; 4) toks mūsų reikalavimams, atsižvelgiant ị visų didžiųjų Valstybių paskelbtąji obalsį: „šis karas eina dèl tiesos, teisès, teisybès, demokratijos ir mažųjų tautų laisvés principų, o labiausia atsimenant gyvus visų didžiųjų valstybių reikalus bei abiejų kariaujančių pusių jiegas, Lietuvos nepriklausomybès pripažinimas, kaipo kompromisinis Lietuvos ateities klausimo išrišimas, gali ir turi rasti prijautimo ir iš vienos ir iš kitos kariaujančių pusių“. Esą prie tokių aplinkybių ne tik galima, bet „būtinai reikia reikalauti Lietuvai nepriklausomybès"110.

${ }^{109}$ Ten pat, p. 10-11.

${ }^{110}$ Ten pat, p. $17-18$. 
Kartu M. Sleževičius nepriklausomybę siejo su Steigiamuoju Seimu, kuriam numatytas svarbiausias vaidmuo nepriklausomoje Lietuvoje: „Išgaukime Lietuvos Steigiamajam Seimui maximum, ką galime išgauti - pilną nepriklausomybę. Turèdamas visa, Jis mokès pasirinkti sau tai, kas Lietuvai bus naudingesnio ir geresnio. Nesiaurinkime tat Lietuvos Steigiamojo Seimo teisių! “111

M. Sleževičiaus supratimu, LSLDP nepriklausomos Lietuvos idealas „visuomenès gyvenime - socializmo tvarka, kur negali būti jokio išnaudojimo ir kur visi žmonès, turèdami lygias teises ir atlikdami vienodas pareigas, lygiai galètų naudotis ir visais darbo mokslo ir kultūros vaisiais“"112. Tiesa, socialistinès santvarkos įvedimas laikytas „dar tolimas idealas, dèl kurio ir mums ir visai žmonijai teks pakelti dar didesnès kovos“. M. Sleževičius, priešingai nei socialdemokratai, išskirdamas dvi socialines grupes, neapsiribojo tik kapitalistais bei proletariatu, bet ir prie išnaudojamos klasės priskyrè, jo žodžiais tariant, visus darbo žmones, visus, kurie „iš savo darbo tik teminta“. Prie darbo žmonių kategorijos priskirti ir mažieji bei vidutiniai ūkininkai, amatininkai, tarnautojai ir pan. Dẻl to LKP socialistus liaudininkus laikè „smulkios ir vidutinès kaimo buržuazijos (mažažemių ir smulkesnių ùkininkų) idealogais"113.

LSLDP su M. Sleževičiumi priešakyje be socializmo sukūrimo kaip galutinio tikslo būsimoje nepriklausomoje Lietuvoje pasisakè už visų tos valstybės gyventojų lygybę, prigimtines žmonių teises ir laisves; tikybos srityje - už sąžinès laisvę; atmesta monarchija (kraštą turètų valdyti patys žmonès per savo rinktuosius atstovus); atstovai ì Seimą turejjo būti renkami be tikejjimo, tautos, lyties skirtumo „tiesiu, lygiu ir betarpiu balsavimu“ pagal proporcinę rinkimų sistemą; Lietuvai tarp kitų valstybių turejo atstovauti šalies prezidentas

${ }^{111}$ Ten pat, p. 24-25,

${ }^{112}$ Sleževičius, M. Ko nori Lietuvos Socialistų-Liaudininkų Demokratų Partija. Voronežas, 1918, p. 12.

${ }^{113}$ Angarietis, Z. ,Revoliuciniai“ liaudininkai. Komunistas. 1918 m., Nr. 16, p. 129. 
(jis galèjo būti renkamas 3-4-5 metams, tokia pačia tvarka kaip ir šalies parlamentas; panašiai turejo būti renkami ir savivaldybių atstovai). Visi pačių žmonių ar jų atstovų valdininkai už savo darbus turèjo atsakyti tik prieš teismą, kuris turèjo būti nemokamas; pasisakyta prieš mirties bausmę bei nuolatinę kariuomenę. Dẻl pastarosios nereikalingumo pateiktas toks argumentas: „Visi krašto piliečiai turi mokytis muštro ir mokèti apsieiti su ginklais, kad priešininkui šalį užpuolus galètų nuo užpuoliko savo tėvynę apginti. Taigi vieton nuolatinès kariuomenès turi būti žmonių milicija“. Finansų srityje pasisakyta už progresyvinius mokesčius; už nemokamą pradinị (jis turèjo būti privalomas), vidurinị ir aukštesnịji mokslą; visos visuomenès ar valstybès išlaikomos mokyklos turẻjo būti pasaulietinès, tikybos mokymas neprivalomas ${ }^{114}$. Pasisakyta už trumpesnę, t. y. 8 val. darbo dieną; visų darbo žmonių apdraudimą (valstybės ir darbdavių lèšomis) nuo ligų, senatvès, nelaimingų atsitikimų ir nedarbo (apdraustos lèšos turèjo būti darbo žmonių atstovų žinioje); prieš vaikų samdomąji darbą ir pan. Lietuvoje bendriems kultūros ir politikos reikalams ginti numatyta ir detis su kitomis demokratinemis Lietuvos partijomis, o „dèl Lietuvos politinès laisvès, kitoms tautoms ar valstybėms ant tos laisvès besikèsinant; dèl Lietuvos vidaus politinio surèdymo, kuris mindžiotų pamatines piliečio teises ir varžytų darbo žmones jų kovoje dèl geresnès socialès tvarkos "115, neatsisakyta ir nuo ginkluotos kovos.

Kad M. Sleževičiaus ir jo vadovaujamos partijos prognozès išsipildytų, pirmiausia reikèjo išspręsti Lietuvos nepriklausomybès klausimą. Tai bandyta daryti 1917 m. pabaigoje - 1918 m. Pirma, Vokietijos valdžiai darant spaudimą Lietuvos Tarybai (LT), 1917 m. gruodžio $11 \mathrm{~d}$. buvo priimtas aktas, kuris Lietuvą su Vokietija turèjo susieti glaudžiais

${ }^{114}$ Sleževičius, M. Ko nori Lietuvos Socialistų-Liaudininkų Demokratų Partija. Voronežas, 1918, p. 15, 19-20.

${ }^{115}$ Sleževičius, M. Ko nori Lietuvos Socialistų-Liaudininkų Demokratų Partija. Voronežas, 1918, p. 22. 
ryšiais $^{116}$. Antra, kadangi toks LT sprendimas sukèlè daug diskusijų ir ne tik gyventojų, bet ir pačios LT nepasitenkinimo, kairieji jos nariai - S. Kairys, Mykolas Biržiška, Stanislovas Narutavičius bei LSLDP atstovas J. Vileišis - iš jos pasitrauke protestuodami. Tokị sprendimą griežtai kritikavo ir LSLDP su M. Sleževičiumi priešakyje $\mathrm{e}^{117}$. Vis dẻlto LT, pasitraukusiems kairiesiems sugrįžus, $1918 \mathrm{~m}$. vasario $16 \mathrm{~d}$. pavyko priimti Lietuvos Nepriklausomybès aktą. Tačiau Vokietijos valdžia pripažino Lietuvą ne pagal vasario $16 \mathrm{~d}$., o pagal gruodžio $11 \mathrm{~d}$. aktą. Tad vasario $16 \mathrm{~d}$. nutarimas iš esmès kurị laiką nepakeitè Lietuvos padèties, nes kitos valstybès Lietuvos nepriklausomybès nepripažino. Net ir pasibaigus Pirmajam pasauliniam karui atkurta nepriklausoma Lietuva susidūrẻ su daugeliu problemų, ir kone didžiausia iš jų - Sovietų Rusijos kariuomenès ekspansija ị Lietuvos teritoriją. 1918 m. pabaigoje prasidejjo Lietuvos nepriklausomybės kovos, kurių metu ką tik iš Rusijos sugrįžusiam M. Sleževičiui, Lietuvos nepriklausomybės šalininkui, teko stoti nepriklausomos Lietuvos vyriausybès priešakyje. Prasidejo naujas $M$. Sleževičiaus politinès veiklos etapas.

\section{Išvados}

1. M. Sleževičius Pirmojo pasaulinio karo metais Lietuvoje, o ją okupavus Vokietijai persikèlęs ị Rusiją daug dèmesio skyrẻ lietuvių pabejgèliams, nukentejusiems nuo karo, šelpti. Nors Lietuvoje jis rūpinosi pabégèliais atstovaudamas kairiųjų ideologijos organizacijai, pasitraukęs ị Rusiją išdrịso ịstoti ị dešiniųjų pažiūrų lietuvių ịsteigtą Lietuvių draugiją nukentejusiems dèl karo šelpti (LDNKŠ). Tai reiškia, kad vardan bendro tikslo, šiuo atveju - lietuvių pabėgèlių, nukentèjusių dèl karo, reikalų, M. Sleževičius, galèjo dirbti ir su politiniais priešininkais. Toks požiūris tuo metu buvo būdingas toli gražu

${ }^{116}$ Lietuva vokiečių okupacijoje Pirmojo pasaulinio karo metais, 1915-1918. Lietuvos nepriklausomos valstybès genezé. Sudarė E. Gimžauskas. Vilnius, 2006, p. 254.

${ }^{117}$ Antroji Lietuvos valstybès konferencija. Kaunas, 1919, p. 45. 
nedaugeliui lietuvių veikèjų. Ta prasme M. Sleževičių galima laikyti kompromisų, o kartu ir konstruktyviu politiniu veikejju.

2. M. Sleževičius Rusijos lietuvių seime Petrograde (RLSP) 1917 m. gegužès pabaigoje - birželio pradžioje, priešingai nei kiti Lietuvos socialistų liaudininkų partijos nariai, kartu su dešiniųjų partijų atstovais pasisakè už Lietuvos nepriklausomybès atkūrimą. Tuo metu jis tuo klausimu buvo tvirtai apsisprendęs. Tačiau balsavimo metu RLSP parėmė ne dešiniųjų pasiūlytą rezoliuciją, kurioje pasisakoma už Lietuvos nepriklausomybès atkūrimą, o balsavo už vadinamąją kairiųjų priimtą rezoliuciją. Ji numatė Lietuvos valstybingumą ateityje sieti su Rusijos klausimu. Toks M. Sleževičiaus elgesys rodo, kad jis tuo metu partijos interesus kèlè aukščiau už savo ịsitikinimus.

3. M. Sleževičiaus principinis nusistatymas dèl Lietuvos nepriklausomybės, aštri polemika su Lietuvos socialistų liaudininkų partijos (LSLP) vadovybe, kuri krypo ị kraštutinę kairę (bolševizmą), o Lietuvos valstybingumo klausimą siejo su Rusijos ateitimi, lėmè Lietuvos socialistų liaudininkų demokratų partijos (LSLDP) atsiradimą. Dėsninga, kad šios naujosios partijos priešakyje atsistojo M. Sleževičius, vienas aršiausių LSLP programinių nuostatų ir pasirinktos taktikos kritikas.

4. 1917 m. pabaigoje - 1918 m. pradžioje veikusi Vyriausioji lietuvių taryba Rusijoje (VLTR) buvo aukščiausia lietuvių politinių partijų, išskyrus bolševikus, organizacija Rusijoje. Tai, kad M. Sleževičius ejjo pirmininko pareigas VLTR, leidžia kalbėti apie didelị šio politinio veikèjo autoritetą tarp kitų lietuvių politikų. Jo kaip politiko pozicijas sustiprino VLTR veikla sudètingomis politinemis sąlygomis, areštas ir îkalinimas su kitais šios organizacijos nariais. Todèl nereikia stebètis, kad 1918 m. pabaigoje sugrịžus ị nepriklausomą Lietuvą M. Sleževičiui, kaip buvusiam VLTR pirmininkui, kritiniu šaliai momentu buvo pasiūlyta stoti Lietuvos valdžios priešakyje.

5. $1918 \mathrm{~m}$. pradžioje, t. y. Lietuvos nepriklausomybės išvakarèse, M. Sleževičius ir toliau primytinai pasisakė už Lietuvos nepri- 
klausomybès atkūrimą. Jo supratimu, nepriklausoma Lietuva turejo būti demokratinè valstybė, kurioje išskirtinis vaidmuo turèjo tekti Steigiamajam Seimui. Tai buvo igyvendinta $1918 \mathrm{~m}$. vasario $16 \mathrm{~d}$. Lietuvos Tarybai priėmus Lietuvos nepriklausomybės aktą. Nors M. Sleževičius šio akto nepasirašè, nes gyveno Rusijoje, tačiau dėsninga, jog M. Sleževičiui pirmaisiais pokario metais teko svarbus vaidmuo ginant Lietuvą nuo išorès priešų. Tuo metu jam buvo suteikta galimybė dèti pastangas, kad Vasario $16 \mathrm{~d}$. nutarimas būtų realizuotas praktiškai.

\title{
POLITICAL ACTIVITIES OF MYKOLAS SLEŽEVIČIUS DURING WORLD WAR I
}

\author{
Mindaugas TAMošaitis
}

\section{Summary}

Keywords: Mykolas Sleževičius, Lithuanian War Relief Society, Petrograd Seimas, Lithuanian Democratic Party, Lithuanian Popular Socialist Party, Lithuanian Popular Socialist Democratic Party, Council of Lithuania, State Council of Lithuania, Council of the Lithuanian Nation, Supreme Lithuanian Council in Russia.

The article focuses on Lithuanian politician Mykolas Sleževičius, a participant of nearly all major events which took place in the political life of Lithuania in the first half of the $20^{\text {th }}$ century. He also played an active part in the Lithuanian Democratic Party (LDP) and was one of the first to bring up the idea of the independence of Lithuania in Petrograd Seimas (RLSP) held in Russia during the years of World War I. The political activities of Sleževičius during the early period (until the restoration of Lithuania's independence in 1918) have not until now received special attention in historiography or they were only presented fragmentarily in the context of the research dealing with other research objects. This article attempts to fill this gap of research. Its aim is to investigate the activities of Mykolas Sleževičius during World War I (1914-1918). The following objectives were set to achieve the aim: to evaluate the joining of Sleževičius to the activities of the right-wing Lithuanian War Relief Society (LDNKŠ) in Russia; to reveal the role of this politician in Petrograd Seimas (RLSP); to analyze the position undertaken by Sleževičius in the context of disagreements 
that occurred within the Lithuanian Popular Socialist Party; to highlight Sleževičius' activities in the Supreme Lithuanian Council in Russia (VLTR); to discuss the position of Mykolas Sleževičius regarding the prospects of Lithuania's independence at the start of 1918 .

The research led to the conclusion that during World War I Sleževičius paid considerable attention to the relief of Lithuanian refugees affected by the war both in Lithuania and later in Russia where he moved after Lithuania was occupied by Germany. Though he aided refugees as a representative of a left-wing organization while in Lithuania, after his withdrawal to Russia he dared to join the right-wing LDNKŠ founded by Lithuanians. It means that driven by the common goal, i. e. the affairs of the relief of Lithuanian refugees affected by the war, Sleževičius could disregard his ideological views and work together with his political opponents. Such an approach was definitely not shared by many Lithuanian public figures at that time. In that sense, Sleževičius can be considered a constructive politician prone to compromise. In the course of Petrograd Seimas held from the end of May to the beginning of June 1917, Sleževičius, as well as other representatives of right-wing parties, advocated for the restoration of Lithuania's independence, as opposed to other members of the Lithuanian Popular Socialist Party. He had a firm position on this issue at that time. However, when voting at Petrograd Seimas, he did not support the resolution proposed by the right, which called for the restoration of Lithuania's independence, but the so called resolution of the left, which advocated for the association of Lithuania's state- hood with the issue of Russia in the future. Such conduct of Sleževičius shows that he placed party interests above his personal beliefs at that time. Sleževičius' principled position concerning Lithuania's independence, his vigorous disputes with the leadership of the Lithuanian Popular Socialist Party (LSLP) inclined towards the extreme left (Bolshevism) and associating the issue of Lithuania's statehood with the future of Russia led to the emergence of the Lithuanian Popular Socialist Democratic Party (LSLDP). It is rather reasonable that the new party was chaired by Mykolas Sleževičius, one of the fiercest critics of the program and tactics selected by the LSLP. The Supreme Lithuanian Council in Russia (VLTR), which operated from the end of 1917 to the beginning of 1918 , was the supreme organization of Lithuanian political parties, with the exception of Bolsheviks, in Russia. Sleževičius' chairmanship in the VLT Rallows us to speak about the great authority of this political figure among other Lithuanian politicians. His political standing was reinforced by the activities of the VLTR under complicated political conditions, arrest and imprisonment together with other members of this organization. It is therefore not surprising that after his return to independent Lithuania at the end of 1918, Sleževičius, as the former chairman of the VLTR, was offered a position at the forefront of the Lithuanian government during the moment critical for the country. At the beginning of 1918, i. e. on the eve of Lithuania's independence, Sleževičius further advocated for the restoration of Lithuania's independence. In his understanding, independent Lithuania had to be a democratic state, in which the Constituent Assembly had a 
special role to play. It was put to life on 16 February 1918 when the Council of Lithuania adopted the Act of Independence of Lithuania. Though Mykolas Sleževičius did not sign this act because he resided in Russia at that time, it is rather natural that he played an important role defending Lithuania from external enemies during the first years after the war. It was the time when he was granted an opportunity to make every effort for the Declaration of 16 February to be put into practice.

Iteikta $2020 \mathrm{~m}$. vasario $7 \mathrm{~d}$. 